\title{
Investigation of the impact of a broad range of temperatures on the physiological and transcriptional profiles of Zymomonas mobilis ZM4 for high-temperature-tolerant recombinant strain development
}

\author{
Runxia Li ${ }^{1}$, Wei Shen ${ }^{2}$, Yongfu Yang ${ }^{1}$, Jun Du ${ }^{3}$, Mian Li ${ }^{4}$ and Shihui Yang ${ }^{1 *}$ (I)
}

\begin{abstract}
The model ethanologenic bacterium Zymomonas mobilis has many advantages for diverse biochemical production. Although the impact of temperature especially high temperature on the growth and ethanol production of $Z$. mobilis has been reported, the transcriptional profiles of $Z$. mobilis grown at different temperatures have not been systematically investigated. In this study, Z. mobilis wild-type strain ZM4 was used to study the effect of a broad range of temperatures of $24,30,36,40$, and $45^{\circ} \mathrm{C}$ on cell growth and morphology, glucose utilization and ethanol production, as well as the corresponding global gene expression profiles using RNA-Seq-based transcriptomics. In addition, a recombinant Z. mobilis strain expressing reporter gene EGFP (ZM4_EGFP) was constructed to study the effect of temperature on heterologous protein expression at different temperatures. Our result demonstrated that the effect of temperature on the growth and morphology of ZM4 and ZM4_EGFP were similar. The biomass of these two strains decreased along with the temperature increase, and an optimal temperature range is needed for efficient glucose utilization and ethanol production. Temperatures lower or higher than normal temperature investigated in this work was not favorable for the glucose utilization and ethanol production as well as the expression of exogenous protein EGFP based on the results of flow cytometry and Western blot. Temperature also affected the transcriptional profiles of Z. mobilis especially under high temperature. Compared with ZM4 cultured at $30^{\circ} \mathrm{C}, 478$ genes were up-regulated and 481 genes were down-regulated at $45^{\circ} \mathrm{C}$. The number of differentially expressed genes of ZM4 cultured at other temperatures $\left(24,36\right.$ or $\left.40^{\circ} \mathrm{C}\right)$ was relatively small though compared with those at $30^{\circ} \mathrm{C}$. Since temperature usually increases during the fermentation process, and heat tolerance is one of the important robustness traits of industrial strains, candidate genes related to heat resistance based on our RNA-Seq result and literature report were then selected for genetics study using the strategies of plasmid overexpression of candidate gene or replacement of the native promoter of candidate gene by an inducible $P_{\text {tet }}$ promoter. The genetics studies indicated that ZMO0236, ZMO1335, ZMO0994, operon groESL, and cspL, which encodes Mrp family chromosome partitioning ATPase, flavoprotein WrbA, an uncharacterized protein, chaperonin Cpn10 and GroEL, and an exogenous cold shock protein,
\end{abstract}

\footnotetext{
*Correspondence: Shihui.Yang@hubu.edu.cn

1 State Key Laboratory of Biocatalysis and Enzyme Engineering, Environmental Microbial Technology Center of Hubei Province, and School of Life Sciences, Hubei University, Wuhan 430062, China

Full list of author information is available at the end of the article
}

(c) The Author(s) 2021. This article is licensed under a Creative Commons Attribution 4.0 International License, which permits use, sharing, adaptation, distribution and reproduction in any medium or format, as long as you give appropriate credit to the original author(s) and the source, provide a link to the Creative Commons licence, and indicate if changes were made. The images or other third party material in this article are included in the article's Creative Commons licence, unless indicated otherwise in a credit line to the material. If material is not included in the article's Creative Commons licence and your intended use is not permitted by statutory regulation or exceeds the permitted use, you will need to obtain permission directly from the copyright holder. To view a copy of this licence, visit http://creativeco mmons.org/licenses/by/4.0/. The Creative Commons Public Domain Dedication waiver (http://creativecommons.org/publicdomain/ zero/1.0/) applies to the data made available in this article, unless otherwise stated in a credit line to the data. 
respectively, were associated with heat tolerance, and recombinant strains over-expressing these genes can improve their heat tolerance. Our work thus not only explored the effects of temperature on the expression of exogenous gene EGFP and endogenous genes, but also selected and confirmed several genes associated with heat tolerance in Z. mobilis, which provided a guidance on identifying candidate genes associated with phenotypic improvement through systems biology strategy and genetics studies for other microorganisms.

Keywords: Zymomonas mobilis, Temperature, Morphology, EGFP, RNA-Seq, Transcriptomics, Heat tolerance

\section{Background}

Biofuel is an attractive substitute of fossil fuels to help address the severe problems of energy crisis and global warming [1, 2]. Yeast is the dominant microorganism for the first-generation bioethanol production. Another native ethanologen, Zymomonas mobilis, has the advantages as the biocatalyst for lignocellulosic biofuel production. Z. mobilis is a facultative anaerobic Gram-negative bacterium, producing ethanol through the unique anaerobic Entner-Doudoroff (ED) pathway [3, 4], which has the following advantages compared with yeast such as high sugar absorption efficiency, high ethanol yield, less biomass, no need to control oxygenation during fermentation, and relatively high tolerance against the inhibitory compounds in the lignocellulosic hydrolysates and the toxic end-products such as isobutanol [5-12].

High-temperature ethanol fermentation (HTEF) is an economic process for the large-scale bioethanol fermentation, which has advantages of reduced pollution risk and cooling costs, higher bioconversion rate, less energy cost for product recovery, and possibility for the more effective process of simultaneous saccharification and fermentation (SSF) than the classical batch fermentation [13, 14]. Based on their differences in growth, metabolism, and genotype, Z. mobilis was subdivided into three subspecies, which were $Z$. mobilis subsp. mobilis, Z. mobilis subsp. pomaceae, and Z. mobilis subsp. Francensis. The dramatic difference between $Z$. mobilis subsp. mobilis and other two subspecies is that $Z$. mobilis subsp. mobilis can grow above $36^{\circ} \mathrm{C}$, while $Z$. mobilis subsp. pomaceae and Z. mobilis subsp. Francensis cannot [15-17].

Temperature, $\mathrm{pH}$, and oxygen level are the common physical factors that affect the growth and fermentation performance of biocatalysts. Previous studies indicated that temperature affected the growth and ethanol production of $Z$. mobilis with biomass and ethanol production reduced at higher temperatures [14, 18, 19]. Temperature also affected the morphology of $Z$. mobilis, and the cell shape changed from short rods under optimal temperature to elongated filaments under high temperature, which is similar to the morphology under other stress conditions such as wood hydrolysate, molasses, urea or various salts [20-22]. Stevnsborg et al. discovered that the shape of $Z$. mobilis cells returned to normal short rods from filaments when the culture temperature was reduced from 36 to $30{ }^{\circ} \mathrm{C}$, and proposed that the arrest of septation and cell division was due to temperaturesensitive enzymes involved in septation [20]. Kosaka et al. further reported that cell elongation of $Z$. mobilis was repressed by $\mathrm{Mg}^{2+}$ at $39{ }^{\circ} \mathrm{C}$ [21]. Although the detailed mechanism behind this phenomenon is not clear, the activity of temperature-sensitive enzymes involved in septation may be stabilized by the $\mathrm{Mg}^{2+}$ at $39^{\circ} \mathrm{C}[20]$.

Temperature not only affects cell morphology, but also changes cell membrane composition, fluidity, and leakage. Benschoter et al. showed that as the temperature increased, the components of saturated fatty acids, cardiolipin, and phosphatidylcholine increased correspondingly, which eventually reduced the membrane fluidity and increased the leakage of intracellular magnesium ions and proteins [23]. Temperature also affects the expression of heterologous proteins. For example, Vigants et al. found out that temperature was inversely proportional to the ratio of sucrose enzyme synthesis and enzymatic activity [24].

To develop robust strains for industrial applications, genes responsive for heat tolerance were identified through systems biology studies, and heat-resistant strains were developed through mutagenesis and metabolic engineering approaches. For example, Charoensuk et al. identified 26 genes related to heat tolerance in $Z$. mobilis through transposon mutagenesis, and classified these genes into nine categories of membrane stabilization, transporter, DNA repair, tRNA modification, protein quality control, translation control, cell division, and transcriptional regulation [25]. Samappito et al. obtained a mutant strain $\mathrm{ZM}$ AD41 through thermal adaptive evolution, the cell length of AD41 at high temperature was shorter than that of wild-type strain. In addition, AD41 grew faster and had better sedimentation performance than the wild-type strain at high temperature [26]. Kosaka et al. performed thermo-adaptive evolution of $Z$. mobilis TISTR548, CP4, and Escherichia coli K-12 strain W3110, which increased the critical high temperature (CHT) of these strains by $2-3{ }^{\circ} \mathrm{C}$ [27]. The cell length of the heat-adapted mutant strains of $Z$. mobilis TISTR548, $\mathrm{CP} 4$, and E. coli W3110 was significantly shorter than 
that of the corresponding wild-type strains or intermediate mutants under their CHTs [21]. They also studied the effects of different metal ions on the high-temperature tolerance of $Z$. mobilis TISTR548, and discovered that the addition of $\mathrm{Mg}^{2+}$ and $\mathrm{K}^{+}$increased a $\mathrm{CHT}$ by $1{ }^{\circ} \mathrm{C}$, reduced intracellular reactive oxygen species (ROS) level, and recovered ethanol productivity, but cell elongation was repressed by $\mathrm{Mg}^{2+}$, but not by $\mathrm{K}^{+}[21]$.

Although quite a few genes related to heat tolerance have been obtained, and the effects of temperature on cellular morphology and growth, sugar utilization and ethanol production as well as the expression of heterologous proteins of $Z$. mobilis have been investigated, nearly all of these works were focused on the performance of $Z$. mobilis under high temperature. There has no systemic research of $Z$. mobilis on a broad temperature range at transcriptional level to better understand the mechanism of heat resistance. In this work, the impact of temperature at a broad range of $24,30,36,40$ and $45^{\circ} \mathrm{C}$ on cellular morphology and growth, glucose utilization and ethanol production, as well as the expression of the exogenous protein EGFP of recombinant strain ZM4_EGFP were studied, and gene expression profiles of $Z$. mobilis ZM4 under different temperatures were investigated using the RNA-Seq based transcriptomics, which help understand cellular responses to temperature systematically and provides gene targets for heat-tolerant recombinant strain development through genetics approaches.

\section{Results and discussion}

Impact of temperature on heterologous gene expression and physiological responses of $Z$. mobilis

To explore the impact of temperature on cell growth and the expression of heterologous protein in Z. mobilis, a recombinant strain ZM4_EGFP carrying the shuttle plasmid fused with reporter gene EGFP [28-30] encoding green fluorescent protein (pEZ_EGFP) was constructed. Our result indicated that the expression of heterologous gene EGFP had minimal impact on cell morphology, growth, glucose utilization and ethanol production compared with the wild-type strain ZM4, while temperature had a great influence on these two strains (Figs. 1, 2).

The microscopic and flow cytometry results of ZM4 and ZM4_EGFP grown at different temperatures are shown in Fig. 1. Within the temperature range of $24-45{ }^{\circ} \mathrm{C}$, cells gradually changed from a short rod shape to a filament shape as the temperature increased (Fig. 1a, b), which was consistent with previous studies [20,27]. At the same time, the results of the flow cytometer were also consistent with those of the microscopic ones (Fig. 1). As the temperature increased, the peak value of FSC

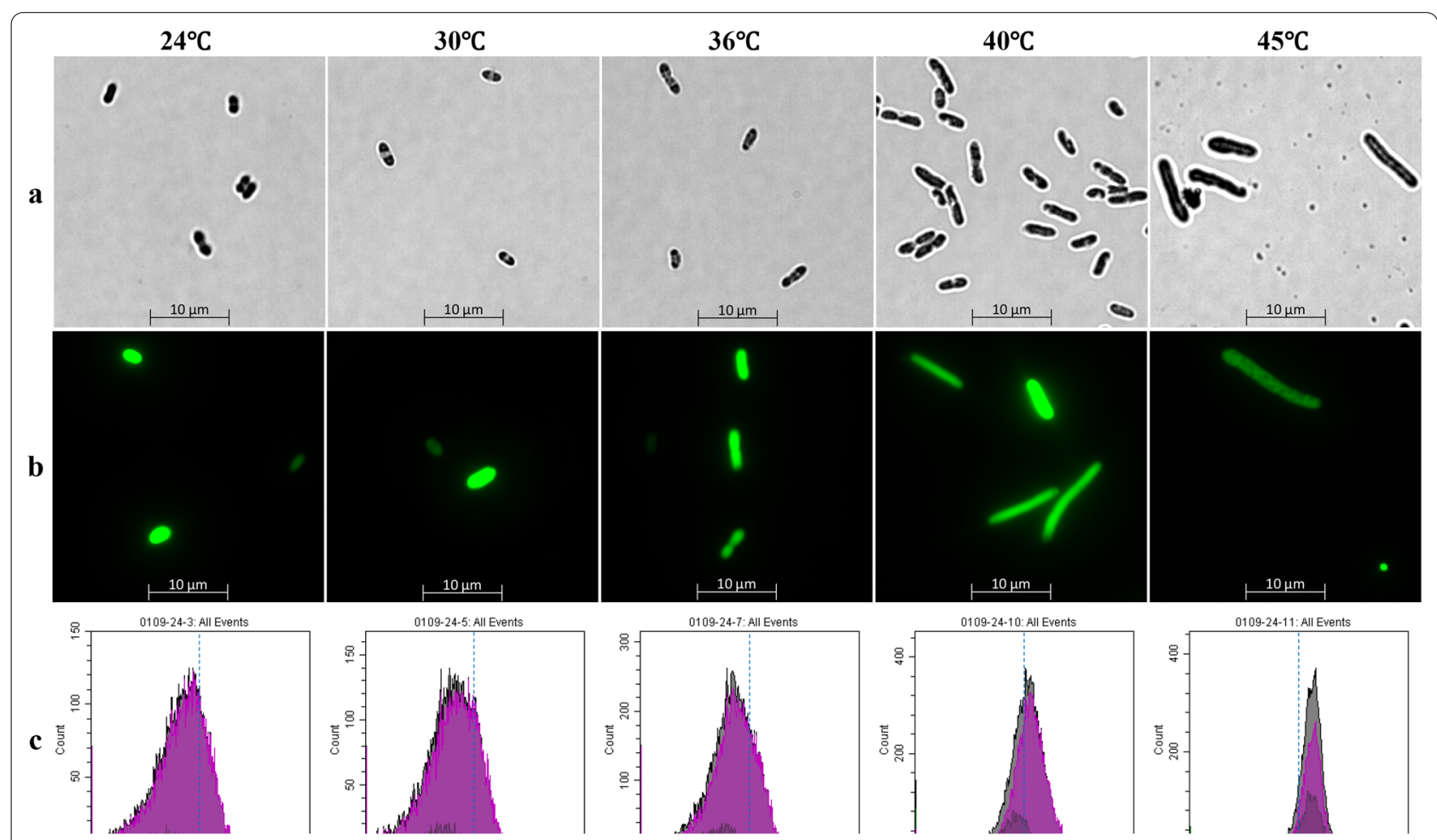

Fig. 1 Microscopic observation of ZM4 (a) and ZM4_EGFP (b) as well as flow cytometry results of ZM4_EGFP (c) grown at different temperatures of $24,30,36,40$, and $45^{\circ} \mathrm{C}$. FSC is a forward scattering angle, generally representative of the volume of the cell 

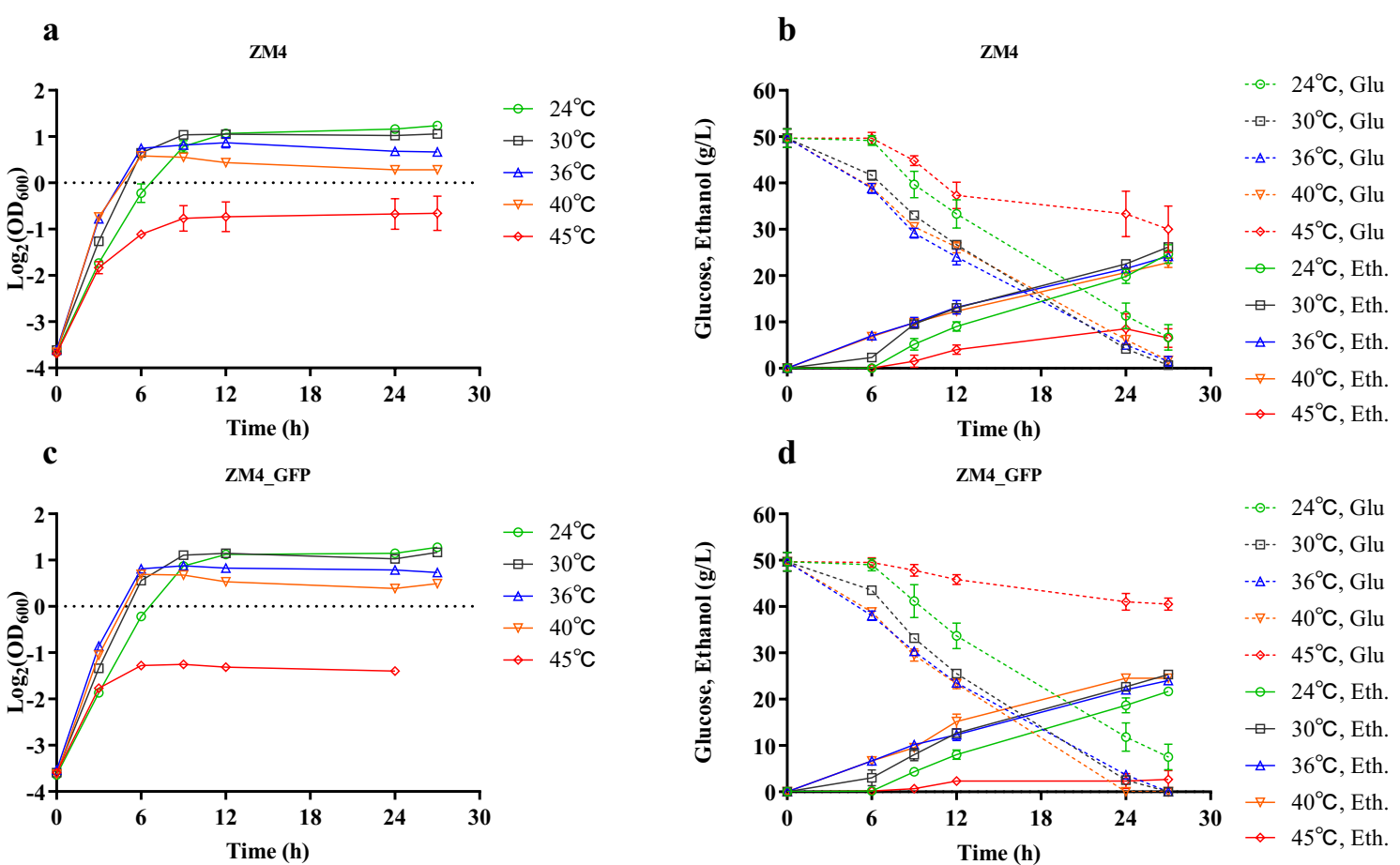

Fig. 2 Cell growth (a), glucose (Glu) consumption and ethanol (Eth) production (b) of ZM4, as well as cell growth (c), glucose (Glu) consumption and ethanol (Eth) production (d) of ZM4_GFP in rich medium (RM) at different temperatures of 24, 30, 36, 40 and $45^{\circ} \mathrm{C}$

that was positively correlated with the cell size gradually increased from less than $10^{4}$ to greater than $10^{4}$ (Fig. 1c).

Cell biomass of the strain, however, decreased along with the increase of temperatures. Compared with the time for ZM4 and ZM4_EGFP to reach stationary phase at normal temperature of $30^{\circ} \mathrm{C}$, the time for $\mathrm{ZM} 4$ and ZM4_EGFP grown at low $\left(24^{\circ} \mathrm{C}\right)$ temperature was longer, while the time for ZM4 and ZM4_EGFP grown at $36{ }^{\circ} \mathrm{C}$ and $40{ }^{\circ} \mathrm{C}$ was shorter (Fig. 2). In the range of 24 and $36{ }^{\circ} \mathrm{C}$, the specific growth rate $(\mu)$ of the two strains increased with the increase of temperature. The specific growth rates of these two strains grown at $36{ }^{\circ} \mathrm{C}$ and $40{ }^{\circ} \mathrm{C}$ were similar while the specific growth rates of two strains grown at $45{ }^{\circ} \mathrm{C}$ were the lowest (Fig. 2 and Additional file 1: Table S1). At high temperatures especially at $45^{\circ} \mathrm{C}$, the ethanol productivity (Qp) of ZM4 decreased significantly compared with normal temperature of $30{ }^{\circ} \mathrm{C}$ (Fig. 2 and Additional file 1: Table S1).

In short, the optimum growth temperature of ZM4 and ZM4_GFP was $30{ }^{\circ} \mathrm{C}$ with the highest biomass within short period of growth time (Fig. 2a, c), and the specific growth rate of both ZM4 and ZM4_GFP increased when temperature increased from 24 to $40{ }^{\circ} \mathrm{C}$ (Fig. 2 and Additional file 1: Table S1). However, both cell growth and sugar to ethanol conversion were severely inhibited when the temperature reached $45^{\circ} \mathrm{C}$, and the overexpression of heterologous protein such as EGFP in this study affected cell growth, glucose consumption, and ethanol production at high temperature of $45{ }^{\circ} \mathrm{C}$ (Fig. 2). Compared with the highest $\mathrm{OD}_{600}$ value around 0.70 for $\mathrm{ZM} 4$ strain at $45{ }^{\circ} \mathrm{C}$, the highest $\mathrm{OD}_{600}$ value of ZM4_GFP strain at $45{ }^{\circ} \mathrm{C}$ was only about 0.40 . Correspondingly, the highest ethanol that ZM4 produced was $8.5 \pm 3.3 \mathrm{~g}$ with $19.7 \pm 6.8 \mathrm{~g}$ glucose consumed while the highest ethanol that ZM4_GFP can produced was only $3.8 \pm 0.4 \mathrm{~g}$ with only $9.2 \pm 2.8$ g glucose consumed within $27 \mathrm{~h}$ post-inoculation (Fig. 2 and Additional file 1: Table S1).

\section{The effect of temperature on the expression of heterologous gene in Z. mobilis}

The introduction of exogenous proteins and metabolic pathways can not only broaden the substrate spectrum of $Z$. mobilis, but also provide the possibility for diverse biochemical production in $Z$. mobilis. Since temperature is one of the important elements that affect the expression and activity of proteins, and there are relatively few reports about the influence of the temperature on heterologous gene expression in $Z$. mobilis, a recombinant $Z$. mobilis strain expressing reporter gene EGFP (ZM4_EGFP) was constructed in this work to study the effects of temperature on the growth and fermentation performance of ZM4_GFP at different temperatures 
as discussed above (Fig. 2c, d). We further investigated the impact of different temperatures on the expression of heterologous gene such as EGFP in ZM4_EGFP using SpectraMax M2e Microplate Reader (Fig. 3a), flow cytometer (data not shown), and Western blot (Fig. 3b), which can be used as a reference for the efforts to express other exogenous genes and to construct metabolic pathways in ZM4 under different temperatures in the future.

Within $12 \mathrm{~h}$, the ratios of fluorescence value/ $\mathrm{OD}_{600}$ increased significantly over time at 30,36 , and $40{ }^{\circ} \mathrm{C}$, but not at the lowest and the highest temperatures of 24 and $45{ }^{\circ} \mathrm{C}$. The ratios of fluorescence value $/ \mathrm{OD}_{600}$ were relatively high at $30,36,40{ }^{\circ} \mathrm{C}$ with the highest ratio of fluorescence $/ \mathrm{OD}_{600}$ at $36{ }^{\circ} \mathrm{C}$ (Fig. 3a). The results of flow cytometer were consistent with the results using a microplate reader (Fig. 3a), both showing that the fluorescence value of individual cell was higher at $36{ }^{\circ} \mathrm{C}$ and $40{ }^{\circ} \mathrm{C}$, which indicated that higher temperatures may be beneficial to the expression of the heterologous EGFP protein with high fluorescence intensity.
The results of Western blot experiments also exhibited that the expression of EGFP protein in the recombinant strain ZM4_EGFP was strong at 30,36 , and $40{ }^{\circ} \mathrm{C}$, while the expression of EGFP protein decreased at $24{ }^{\circ} \mathrm{C}$ and especially at $45^{\circ} \mathrm{C}$ (Fig. 3b). Similar to the results of Fig. 3a, high temperature $\left(45^{\circ} \mathrm{C}\right)$ was disadvantageous for heterologous EGFP protein expression or caused protein degradation due to cell lysis (Fig. 3b).

\section{Effects of temperatures on global transcriptional profiles of Z. mobilis}

The effect of temperature on the transcriptional level of the entire genome was investigated by RNA-Seq transcriptomics to explore genes responsive for temperature changes. Genes that were differentially expressed in response to temperature raise and those at high temperature can be used to identify gene targets for heat-tolerant strain construction. The RNA-seq results obtained by culturing $\mathrm{ZM} 4$ at different temperatures showed that gene expression fluctuates significantly at $45^{\circ} \mathrm{C}$ (Fig. 4).

\section{$\mathbf{a}$}

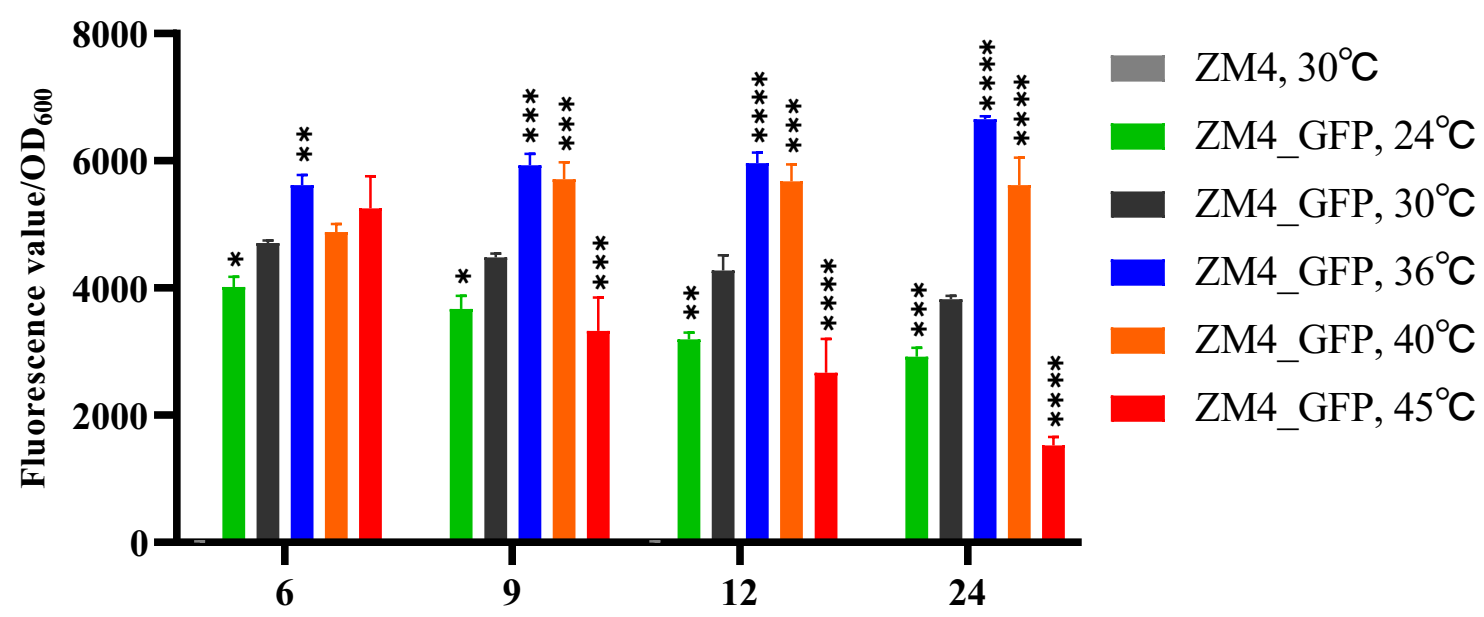

Time (h)

b

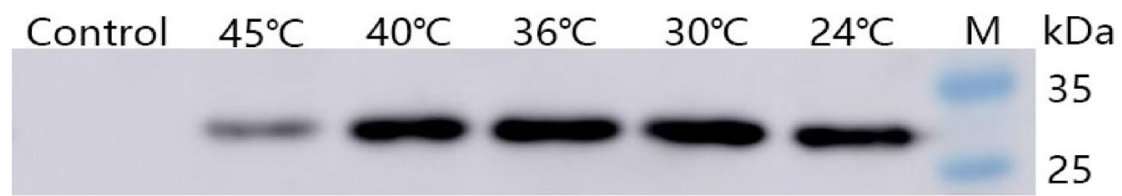

Fig. 3 The ratios of fluorescence value/OD 600 of recombinant strain ZM4_EGFP at different temperatures of $24,30,36,40$, and $45^{\circ} \mathrm{C}$ using a microplate reader (a), and Western blot result of EGFP in ZM4_EGFP cultured at different temperatures of $24,30,36,40$, and $45^{\circ} \mathrm{C}(\mathbf{b}) . " \mathrm{ZM} 4,30^{\circ} \mathrm{C}$ " indicated the control condition of wild-type strain ZM4 grown at $30^{\circ} \mathrm{C}$. Control represented wild-type strain ZM4 cultured at $30{ }^{\circ} \mathrm{C}$. M was Pre-dyed SDS-PAGE Standard. One-way ANOVA of the ratios of fluorescence intensity value and $\mathrm{OD}_{600}$ of $Z \mathrm{ZM} 4$ _GFP at $24,36,40$, and $45^{\circ} \mathrm{C}$ were conducted with $30^{\circ} \mathrm{C}$ as a control at $6,9,12$, and $24 \mathrm{~h}$, respectively, ${ }^{*}$ represents a significant difference $(0.01<P$-value $<0.05)$, ${ }^{* *}$ represents a very significant difference $(P$-value $<0.01),{ }^{* * *}$ represents $P$-value $<0.001,{ }^{* * * *}$ represents $P$-value $<0.0001$ 

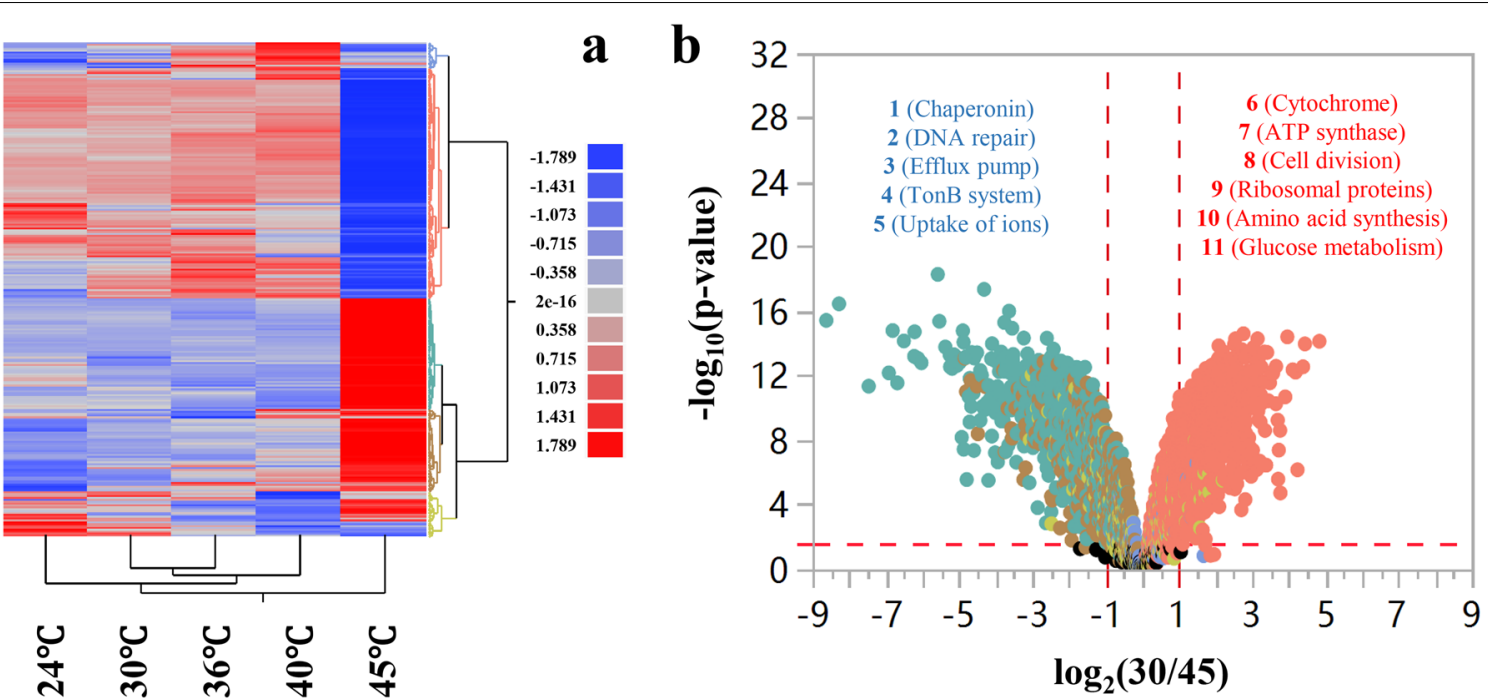

Fig. 4 Heatmap analysis of ZM4 transcriptional profiles at different temperatures of $24,30,36,40$, and $45^{\circ} \mathrm{C}(\mathbf{a})$, and Volcano plots of significantly differentially expressed genes of $Z$. mobilis cultured at $30^{\circ} \mathrm{C}$, compared with $45^{\circ} \mathrm{C}(30 / 45)(\mathbf{b})$. In $\mathbf{b}$, the dots above the horizontal red dash line indicate genes significantly differentially expressed, and the vertical red dash line indicate genes significantly differentially expressed with ratio greater than 2 ( $\log _{2}$-based ratio greater than 1$)$. Gene name with red and blue color font indicates up-regulated and down-regulated genes of ZM4 cultured at $30^{\circ} \mathrm{C}$ compared with $45^{\circ} \mathrm{C}$, respectively. The numbers $1-5$ referred to genes related to chaperonin, DNA repair, efflux pump, TonB system, and ions uptake, respectively. The numbers 6-11 referred to genes related to cytochrome, ATP synthesis, cell division, ribosomal proteins, amino acid synthesis, and glucose metabolism, respectively

Among significantly differentially expressed genes, there were 478 genes up-regulated and 481 genes downregulated in $\mathrm{ZM} 4$ cultured at $45{ }^{\circ} \mathrm{C}$ compared with $30{ }^{\circ} \mathrm{C}$, which showed that the temperature had a significant effect on transcriptomic profiles, especially at $45{ }^{\circ} \mathrm{C}$ (Fig. 4a). Compared with normal temperature $30{ }^{\circ} \mathrm{C}, \mathrm{ZM} 4$ had fewer differentially expressed genes at low temperature $\left(24{ }^{\circ} \mathrm{C}\right)$ and other temperatures examined in this study $\left(36^{\circ} \mathrm{C}, 40^{\circ} \mathrm{C}\right)$. In terms of temperature increase $(24 / 30,30 / 36,36 / 40,40 / 45)$, when the culture temperature did not exceed $40{ }^{\circ} \mathrm{C}$, the number of differentially expressed genes was less than a hundred, but it can be clearly seen that compared with $40^{\circ} \mathrm{C}$, the number of differentially expressed genes in ZM4 exceeded 1000 under high temperature of $45{ }^{\circ} \mathrm{C}$ (Table 1). Compared with those at $30{ }^{\circ} \mathrm{C}, 959$ genes including those encoding chaperones, cell division proteins, out membrane transporters were significantly differentially expressed at $45^{\circ} \mathrm{C}$, accounting for more than half of the total genes of ZM4 (Fig. 4b and Additional file 2: Table S2).

Compared with normal temperature of $30{ }^{\circ} \mathrm{C}$, the genes encoding chaperone proteins (DnaK, DnaJ, ClpB, Cpn10, and GroEL), TonB-related proteins (ZMO0789, ZMO0902, ZMO1040, ZMO1463, ZMO1522, ZMO0561, ZMO1298, ZMO1986, ZMO1631, ZMO1815, and ZMO1822), DNA repair-related

Table 1 Number of significantly differentially expressed genes at different temperatures, the numbers in the brackets are the numbers of up-regulated and down-regulated genes, respectively

\begin{tabular}{lll}
\hline Comparisons & $\begin{array}{l}\text { Number of differentially expressed genes (up-regulated, } \\
\text { down-regulated) }\end{array}$ & $\begin{array}{l}\text { Subtab number in Additional } \\
\text { file 2: Table S2 for detailed } \\
\text { information }\end{array}$ \\
\hline $30 / 45$ & $959(481,478)$ & Table S2_a \\
$30 / 40$ & $81(54,27)$ & Table S2_b \\
$30 / 36$ & $21(20,1)$ & Table S2_c \\
$24 / 30$ & $12(12,0)$ & Table S2_d \\
$40 / 45$ & $1014(527,487)$ & Table S2_e \\
$36 / 40$ & $62(23,39)$ & Table S2_f
\end{tabular}

For example, “30/45" referred to differentially expressed genes between ZM4 cultured at $30^{\circ} \mathrm{C}$ and $45^{\circ} \mathrm{C}$. Differentially expressed genes at different temperatures are listed in Additional file 2: Table S2 
proteins (RecA, RedC, RecR, RecF, MutL, and MutS), and efflux pump-related proteins (ZMO0965, ZMO0282, ZMO0283, and ZMO0287) were up-regulated in ZM4 cultured at the high temperature of $45^{\circ} \mathrm{C}$. It was reported that the upregulation of genes encoding chaperone proteins can improve the stress resistance of cells [31]. The overexpression of chaperone proteins under high temperature may be one of the strategies that cells imply to deal with the damages caused by heat stress.

Interestingly, more than $70 \%$ of TonB-related proteins in ZM4 were up-regulated at $45{ }^{\circ} \mathrm{C}$. More than twothirds of Gram-negative bacteria possessed the TonB system, which plays an important role in the intake of various nutrients such as vitamin $B_{12}$, carbohydrates, iron and zinc ions [32-36]. Meanwhile, in the transcriptome data, genes related to the uptake of iron ions $(Z M O 0423$, $Z M O 0428, Z M O 0429$, and ZMO1596) and zinc ions (ZMO1236 and ZMO1341) were up-regulated at high temperature. These results suggested that cells may upregulate genes associated with TonB system and transporters of important nutrients to maintain normal cell metabolism by promoting the uptake of nutrients and cofactors under the high temperature stress condition.

As a cofactor of many enzymes and necessary for the stability of zinc finger proteins, zinc was associated with cellular metabolism including stress responses and biosynthesis of plasma membrane, such as biosynthesis of phospholipid in Saccharomyces cerevisiae and biosynthesis of ergosterol and trehalose in self-flocculating yeast [37-39]. The supplementation of zinc significantly improved the ethanol and heat tolerance of self-flocculating yeast, which was closely related to the increased ergosterol and trehalose contents in the yeast flocs [37]. The upregulation of genes related to the uptakes of iron and zinc in this study suggested that a similar role of zinc may also exist in $Z$. mobilis to help stabilize the structure of cell membranes and enzyme activities in response to heat and ethanol stresses.

Genes down-regulated under high temperature compared with normal temperature mainly involved in energy metabolism and protein biosynthesis such as ATP synthase-related genes (ZMO1686, ZMO0667, ZMO0239, ZMO0669, ZMO0671, ZMO0241, ZMO0668, ZMO0242, $Z M O 0240$, and $Z M O 0238)$, cytochrome-related genes (ZMO0957, ZMO1571, ZMO1258, ZMO1255, $Z M O 1253, Z M O 1572$, and ZMO0806), glucose metabolism-related genes (ZMO1757, ZMO1756, ZMO1649, $Z M O 0366, Z M O 1981$, and ZMO0689), glutamate, histidine, and cysteine synthesis-related genes (ZMO1117, ZMO0457, ZMO1964, ZMO0783, ZMO0782, ZMO0784; ZMO0480, ZMO1105, ZMO1962, ZMO0752, ZMO1508; $Z M O 0005, Z M O 0007$, and $Z M O 0008)$, as well as ribosome protein-related genes (ZMO0884, ZMO0532,
ZMO1079, ZMO0534, and ZMO1145). The down-regulation of genes related to glucose metabolism at high temperature was consistent with the decrease of glucose consumption in ZM4 at high temperature (Fig. 2). The down-regulation of genes related to cellular respiratory chain and protein biosynthesis could be a strategy for cell survival by reducing energy consumption in response to extreme environments, and the down-regulation of genes related to cell division (ZMO0830 and ZMO0835) under high temperature may lead to a decrease in the frequency of cell division and thus the phenomenon of cell lengthening (Fig. 1).

We further drew two Venn diagrams for four datasets of differentially expressed genes of ZM4 cultured at different temperatures of $24,36,40$, and $45{ }^{\circ} \mathrm{C}$ compared with $30{ }^{\circ} \mathrm{C}$ (Fig. 5a), and four datasets of differentially expressed genes of ZM4 with the increase of temperatures from 24 to $45{ }^{\circ} \mathrm{C}$ gradually (Fig. 5b) to identify common genes that are potentially responsive to temperature changes. Our results indicated that the differences between differentially expressed genes due to temperature raise from 24 to $45^{\circ} \mathrm{C}$ or different temperature comparisons with $30^{\circ} \mathrm{C}$ were similar (Fig. 5). There were too many differentially expressed genes for ZM4 cultured at $45{ }^{\circ} \mathrm{C}$ compared $30{ }^{\circ} \mathrm{C}$ as well as $45{ }^{\circ} \mathrm{C}$ compared with $40^{\circ} \mathrm{C}$, and high temperature of $45^{\circ} \mathrm{C}$ had great impact on global gene expression.

Forty-nine genes in the region that overlaps with the differentially expressed genes of ZM4 cultured at $45{ }^{\circ} \mathrm{C}$ compared with $30^{\circ} \mathrm{C}\left(\right.$ " $\left.30 / 45^{\prime \prime}\right)$ with those from the comparisons of " $24 / 30$ ", "30/36", and "30/40" were likely to respond to heat stress (Fig. 5a and Table 2). Similarly, genes related to chaperonin and DNA repair were mainly up-regulated at high temperature, while genes related to glucose metabolism and amino acid synthesis were down-regulated at high temperature. Eleven genes shown in bold font in Table 2 were up-regulated in both high $\left(45^{\circ} \mathrm{C}\right)$ and low temperature $\left(24{ }^{\circ} \mathrm{C}\right)$ conditions than at normal temperatures $\left(30^{\circ} \mathrm{C}\right.$ ) (Additional file 3: Table S3). These temperature-responsive genes could serve as temperature control switches to the changing temperatures.

\section{Selection and characterization of heat-tolerant candidate genes}

Among three subspecies of Z. mobilis, Z. mobilis subsp. mobilis is heat resistant, while $Z$. mobilis subsp. pomaceae and Z. mobilis subsp. francensis are not [15]. The complete protein sequences of ZM4 were compared with those of ATCC 29192 that is belonging to subsp. pomaceae with 12 genes unique to ZM4 identified, which could be potentially heat-tolerant genes in ZM4. The expression values of these genes are listed in Table 3. 
a

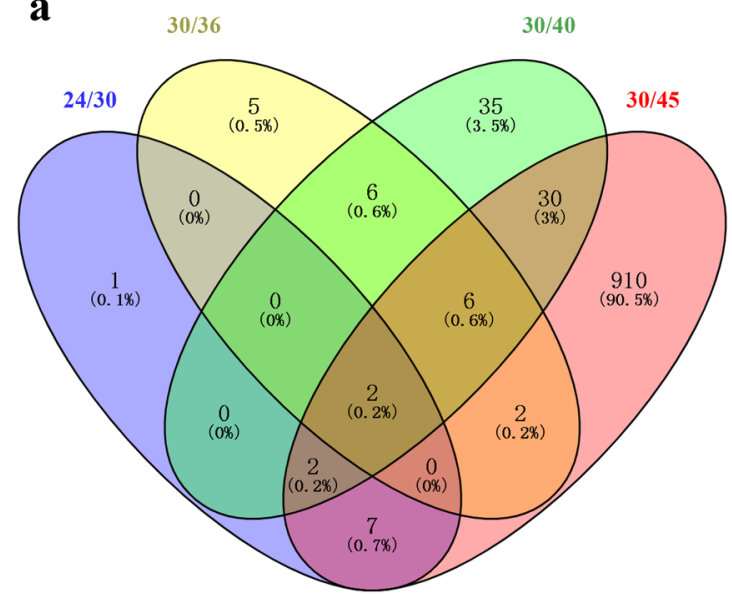

b

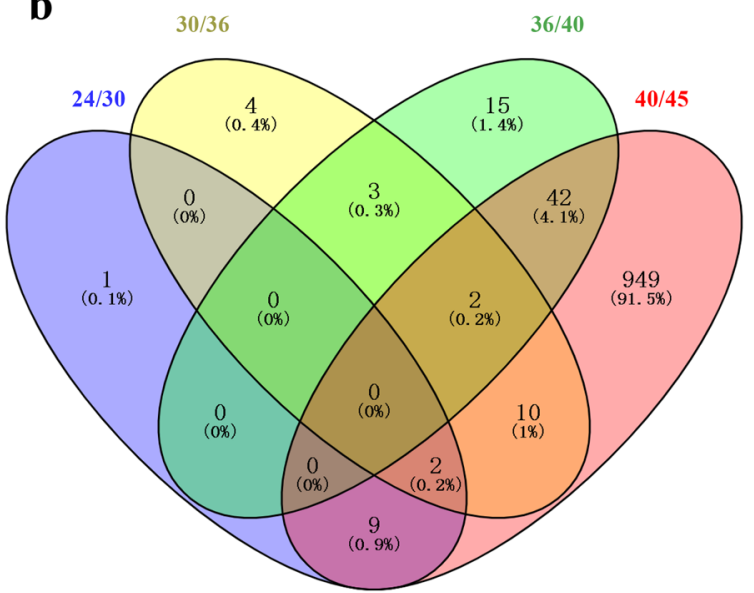

Fig. 5 Venn diagram of differential expressed genes of ZM4 cultured at $24^{\circ} \mathrm{C}$ compared with $30^{\circ} \mathrm{C}(24 / 30)$, ZM4 cultured at $30^{\circ} \mathrm{C}$ compared with $36^{\circ} \mathrm{C}(30 / 36), Z M 4$ cultured at $30^{\circ} \mathrm{C}$ compared with $40^{\circ} \mathrm{C}(30 / 40)$, and ZM 4 cultured at $30^{\circ} \mathrm{C}$ compared with $45^{\circ} \mathrm{C}(30 / 45)$ (a). Venn diagram of differential expressed genes with the raise of temperature gradually for ZM 4 cultured at $24^{\circ} \mathrm{C}$ compared with $30^{\circ} \mathrm{C}(24 / 30), Z M 4$ cultured at $30^{\circ} \mathrm{C}$ compared with $36^{\circ} \mathrm{C}(30 / 36), \mathrm{ZM} 4$ cultured at $36^{\circ} \mathrm{C}$ compared with $40^{\circ} \mathrm{C}(36 / 40)$, and ZM4 cultured at $40^{\circ} \mathrm{C}$ compared with $45^{\circ} \mathrm{C}(40 / 45)(\mathbf{b})$

Through transposon mutagenesis, Charoensuk et al. found 26 genes related to heat tolerance in Z. mobilis TISTR 548 (ATCC 29191) [25]. The protein sequences of these genes were also compared with complete ZM4 protein sequences to identify their homologous proteins in ZM4, and the expression values of genes in ZM4 with homologues in Z. mobilis TISTR 548 that were reported to be associated with heat tolerance at different temperatures are summarized in Table 4.

At $45^{\circ} \mathrm{C}$, the expression of $Z M O 1636$ (membrane stability), ZMO0234 (protein quality control), ZMO0236 (cell division), and ZMO1335 (transcription control) were significantly increased in ZM4 (Table 4). There are about $500 \mathrm{bp}$ DNA fragment between ZMO0234 and $Z M O 0236$, which could be a bi-directional promoter, driving the transcription of both ZMO0234 and ZMO0236. Considering the expression levels of $Z M O 0234$ and $Z M O 0236$ increased significantly at $45^{\circ} \mathrm{C}$ (Table 4), it is possible that regulatory elements related to thermal stability exist within the 500 bp DNA fragment between these two genes.

The constitutive overexpression of GroEL, GroES, and ClpB in Pseudomonas putida KT2440 can improve its tolerance to a variety of thermochemical wastewater samples [31]. The first two proteins can form a GroESL complex for protein folding. The function of $\mathrm{ClpB}$ is to depolymerize the protein, by combining with DnaJKE and/or GroESL complexes to break down and refold the protein aggregates into functional proteins. In addition, overexpression of ZMO0994 gene of Z. mobilis in E. coli DE3 improved the tolerance of DE3 to abiotic stresses such as ethanol, furfural, hydroxymethyl furfural, and heat [26], indicating that ZMO0994 is associated with the resistance to abiotic stress. However, this impact of overexpression of ZMO0994 gene on heat tolerance in $Z$. mobilis has not been explored yet. In addition to the chaperones discussed above, cold shock protein CspL from the thermophilic bacterium Bacillus coagulans 2-6 was systematically investigated recently, and the results demonstrated that CspL plays a role in heat tolerance, which can promote the growth of diverse microorganisms under heat stress including E. coli $\mathrm{DH} 5 \alpha, S$. cerevisiae INVSc1, and P. putida KT2440 through binding diverse RNA species at high temperatures [40].

Based on the results in Tables 3 and 4, the following genes were selected for recombinant strain construction to verify whether these genes are related to heat resistance in Z. mobilis. ZM4_014, ZM4_005, ZM4_028, ZM4_1465, ZM4_1483, ZM4_1628, ZM4_2037, ZM4_0234, ZM4_0236, ZM4_1335, ZM4_1636, ZM4_0015 referred to recombinant strains overexpressing genes of $p Z Y M 32 \_014$ (an operon including genes pZYM32_012-015), pZYM36_005, pZYM32_028, ZMO1465, ZMO1483, ZMO1628, ZMO2037, ZMO0234, $Z M O 0236, Z M O 1335, Z M O 1636$, and ZMO0015 by homologous recombination to replace the native promoters of these genes with a tetracycline inducible promoter $\mathrm{P}_{t e t}$, respectively. In addition, genes encoding the chaperone proteins, an uncharacterized protein, and an exogenous cold shock protein CspL were overexpressed using the shuttle plasmid pEZ15Asp [41] to obtain recombinant strains ZM4 (pEZ_clpB), ZM4 (pEZ_clpB_groESL), ZM4 (pEZ_groESL), ZM4 (pEZ_0994), and ZM4 (pEZ_ cspL), respectively. 
Table 2 List of 49 significantly differentially expressed genes between ZM4 cultured at $30{ }^{\circ} \mathrm{C}$ and $45^{\circ} \mathrm{C}$

\begin{tabular}{|c|c|c|c|}
\hline Gene ID & Product & Ratio & $-\log _{10}(P$-value $)$ \\
\hline \multicolumn{4}{|c|}{ Upregulated gene in ZM4 cultured at $30^{\circ} \mathrm{C}$ compared with $45^{\circ} \mathrm{C}$} \\
\hline ZMO0005 & Sulfate adenylyltransferase small subunit & 1.35 & 3.24 \\
\hline ZMO0008 & Sulfite reductase hemoprotein beta-component & 1.31 & 2.59 \\
\hline ZMO0374 & Levansucrase & 1.83 & 5.90 \\
\hline ZMO0375 & Levansucrase/invertase & 1.64 & 5.43 \\
\hline ZMO0379 & PBSX family phage terminase large subunit & 1.53 & 5.18 \\
\hline ZMO0395 & Hypothetical protein & 2.20 & 5.52 \\
\hline ZMO0397 & Hypothetical protein & 1.84 & 4.79 \\
\hline ZMO0454 & Formate-tetrahydrofolate ligase & 2.39 & 10.71 \\
\hline ZMO0492 & Nitrogen regulatory protein P\|I & 3.16 & 11.78 \\
\hline ZMO1117 & Glutamate synthase large subunit & 1.44 & 7.99 \\
\hline ZMO1719 & Fructokinase & 1.73 & 10.52 \\
\hline ZMO1748 & ArsR family transcriptional regulator & 1.36 & 5.73 \\
\hline ZMOp36×011 & Tail sheath protein & 1.82 & 4.51 \\
\hline ZMOp36×012 & Tail tube protein & 1.60 & 4.35 \\
\hline \multicolumn{4}{|c|}{ Downregulated gene in ZM4 cultured at $30^{\circ} \mathrm{C}$ compared with $45^{\circ} \mathrm{C}$} \\
\hline ZMO0122 & Uncharacterized protein & -2.86 & 9.99 \\
\hline ZMO0286 & DUF541 domain-containing protein & -2.56 & 9.78 \\
\hline ZMO0693 & OsmC family protein & -1.57 & 8.5 \\
\hline$Z M 00740$ & General stress protein CsbD & -3.06 & 8.03 \\
\hline ZMO1113 & FAD-dependent pyridine nucleotide-disulfide oxidoreductase & -1.62 & 8.34 \\
\hline ZMO1237 & Lactate dehydrogenase & -2.82 & 9.39 \\
\hline ZMO1522 & TonB-dependent receptor & -1.01 & 3.88 \\
\hline ZM01533 & Hypothetical protein & -3.01 & 12.07 \\
\hline ZMO1754 & Succinate-semialdehyde dehydrogenase SSADH & -3.95 & 11.33 \\
\hline ZM01776 & Aminopeptidase $\mathrm{N}$ & -1.97 & 9.64 \\
\hline ZMO1940 & Hypothetical protein & -4.87 & 7.45 \\
\hline ZMO0003 & Adenylyl-sulfate kinase & -1.23 & 2.12 \\
\hline ZMO0246 & ATP-dependent protease subunit HsIV & -2.06 & 11.16 \\
\hline ZMO0400 & Hypothetical protein & -1.17 & 5.94 \\
\hline ZMO0422 & BadM/Rrf2 family transcriptional regulator & -1.25 & 7.82 \\
\hline ZMO0660 & Chaperone protein DnaK & -3.52 & 10.65 \\
\hline ZMO0748 & Cysteine synthase & -3.3 & 9.68 \\
\hline ZMO0989 & Heat-shock protein IbpA & -8.63 & 15.44 \\
\hline ZMO1062 & Putative phage shock protein pspD & -2.33 & 8.1 \\
\hline ZMO1063 & Phage shock protein A PspA & -2.9 & 10.94 \\
\hline ZMO1271 & Siroheme synthase CysG & -4.29 & 11.34 \\
\hline ZMO1424 & ATP-dependent chaperone ClpB & -1.82 & 11.22 \\
\hline ZMO1426 & DNA repair protein RadC & -1.22 & 6.63 \\
\hline ZMO1463 & TonB-dependent receptor & -1.41 & 4.44 \\
\hline ZMO1586 & Bacterioferritin & -1.46 & 5.72 \\
\hline ZMO1721 & Glyoxalase/bleomycin resistance protein dioxygenase & -4.59 & 13.11 \\
\hline ZMO1849 & Uncharacterized protein & -3.55 & 8.15 \\
\hline ZMO1928 & Chaperonin Cpn10 & -6.22 & 13.21 \\
\hline ZMO1929 & Chaperonin GroEL & -6.03 & 12.81 \\
\hline ZMOp33×029 & Azospirillum phage Cd Gp10 family protein & -2.4 & 7.07 \\
\hline ZMOp33×030 & Hypothetical protein & -2.45 & 8.57 \\
\hline ZMOp39x009 & Putative partitioning protein ParA ATPase & -1.39 & 8.45 \\
\hline ZMOp39x010 & Putative partitioning protein ParB & -1.23 & 6.27 \\
\hline ZMOp39x036 & Hypothetical protein & -3.79 & 12.36 \\
\hline ZMOp39×037 & Hypothetical protein & -4.21 & 11.34 \\
\hline
\end{tabular}


Table 2 (continued)

Ratio is the $\log _{2}$-based expression difference between ZM4 cultured at $30^{\circ} \mathrm{C}$ and $45^{\circ} \mathrm{C}$. Gene name with red and blue color font indicates up-regulated and downregulated at $30^{\circ} \mathrm{C}$ compared with $45^{\circ} \mathrm{C}$, respectively. Eleven genes shown in bold font were up-regulated in both high $\left(45^{\circ} \mathrm{C}\right)$ and low temperature $\left(24^{\circ} \mathrm{C}\right)$ conditions than at normal temperatures $\left(30^{\circ} \mathrm{C}\right.$ ) (Additional file 3: Table S3)

Table 3 Unique genes of ZM4 compared with ATCC 29192 and their expression values $\left(\log _{2}\right.$ RPKM) at different temperatures

\begin{tabular}{|c|c|c|c|c|c|c|}
\hline \multirow[t]{2}{*}{ Gene ID } & \multirow[t]{2}{*}{ Product } & \multicolumn{5}{|c|}{$\log _{2} R P K M$} \\
\hline & & $24^{\circ} \mathrm{C}$ & $30^{\circ} \mathrm{C}$ & $36^{\circ} \mathrm{C}$ & $40^{\circ} \mathrm{C}$ & $45^{\circ} \mathrm{C}$ \\
\hline ZMO1465 & Hypothetical protein & 8.09 & 8.38 & 8.40 & 7.95 & 6.25 \\
\hline ZMO1483 & Hypothetical protein & 2.07 & 2.43 & 2.30 & 3.15 & 3.52 \\
\hline ZMO1628 & PepSY-associated TM helix domain protein & 5.24 & 5.20 & 5.45 & 5.45 & 5.77 \\
\hline ZMO2037 & Hypothetical protein & 3.31 & 2.51 & 2.41 & 3.03 & 7.63 \\
\hline pZYM32_014 & Hypothetical protein & 7.31 & 7.43 & 6.93 & 8.02 & 10.71 \\
\hline pZYM32_016 & Hypothetical protein & 0.50 & 0.25 & 0.00 & 0.00 & 0.00 \\
\hline pZYM32_028 & Hypothetical protein & 6.98 & 7.03 & 7.05 & 7.51 & 6.47 \\
\hline pZYM36_005 & Phage morphogenesis protein & 4.82 & 5.05 & 4.50 & 5.19 & 7.01 \\
\hline pZYM36_026 & Hypothetical protein & 6.24 & 6.23 & 5.98 & 5.61 & 5.93 \\
\hline pZYM36_030 & Hypothetical protein & 9.22 & 9.47 & 8.96 & 8.94 & 10.93 \\
\hline pZYM36_037 & Hypothetical protein & 6.66 & 6.59 & 6.29 & 6.31 & 6.58 \\
\hline pZYM36_045 & Small terminase subunit & 4.80 & 4.54 & 4.06 & 5.32 & 5.66 \\
\hline
\end{tabular}

The results showed that ZM4_0236 and ZM4_1335 grew better than the wild-type ZM4 under $0 \mu \mathrm{g} / \mathrm{mL}$ tetracycline induction (Fig. 6c, g), indicating that the overexpression of above two genes is beneficial to improve the growth of ZM4 at high temperature. It needs to be pointed out that when the tetracycline concentration was $0 \mu \mathrm{g} / \mathrm{mL}$, the $P_{\text {tet }}$ promoter is still functional due to the leaky background expression of $\mathrm{P}_{\text {tet }}$ promoter. However, ZM4_014 or ZM4_0015 grew significantly worse when operon $p Z Y M 32$ 012-015 or gene ZMO0015 was overexpressed with $0.2 \mu \mathrm{g} / \mathrm{mL}$ tetracycline induction compared with no tetracycline induction (Fig. 6a-d, g, h). ZMO0015 encodes the heat-induced transcriptional repressor HcrA, which is a negative regulator of heat shock-like genes ( $g r p E$-dnaK-dnaJ and groELS operons) and prevents heat shock induction of these heat shock genes. ZM4_014 was obtained by replacing the promoter of pZYM32_012-015 operon encoding several hypothetical proteins. Under $0.2 \mu \mathrm{g} / \mathrm{mL}$ tetracycline induction conditions, the tolerance of ZM4_014 and ZM4_0015 to high temperature was significantly reduced, which indicated that overexpression of these genes resulted in heat sensitive instead of heat tolerance.

For mutants over-expressing candidate genes using shuttle vector pEZ15Asp, recombinant strains of ZM4 (pEZ-0994) and ZM4 (pEZ_cspL) grew significantly better than the control strain ZM4 (pEZ_Ep) (Fig. 6e-h), which was consistent with previous reports that the overexpression of gene ZMO0994 and heterologous gene $\operatorname{csp} L$ can help promote cellular growth significantly at a high temperature $[26,40]$. In addition, when only groESL operon was overexpressed, the specific growth rate of recombinant strain ZM4 (pEZ_groESL) was significantly higher than that of ZM4 (pEZ_Ep) at high temperatures (Fig. 6e-h), which was also consistent with previous report in P. putida [31]. However, when groESL was overexpressed together with $\operatorname{clp} B$ or $\operatorname{clp} B$ was overexpressed alone, both recombinant strains of ZM4 (pEZ clpB_groESL) and ZM4 (pEZ_clpB) grew worse than the control strain ZM4 (pEZ_Ep) at the concentration of 0 and $0.2 \mathrm{ug} / \mathrm{mL}$ tetracycline (Fig. 6e, f). Further study is needed to help understand the role of $c l p B$ and the effect of different combinations of chaperone genes on heat tolerance in $Z$. mobilis.

\section{Conclusion}

The effects of a broad range of temperatures at 24, 30, 36,40 , and $45{ }^{\circ} \mathrm{C}$ on cell growth, fermentation performance, heterologous protein expression, and global transcriptional profiles of $Z$. mobilis have been systematically investigated in this study. Our result indicated that temperature especially high temperature affected cell morphology and growth, sugar utilization and ethanol production, as well as the expression of exogenous protein such as EGFP. In addition, temperature affected the transcriptional profiles of $Z$. mobilis especially at high temperature with 478 genes up-regulated and 481 genes 
Table 4 The expression values ( $\log _{2}$ RPKM) of genes in ZM4 corresponding to 26 genes related to heat tolerance of Z. mobilis TISTR 548 (ATCC 29191) at different temperatures

\begin{tabular}{|c|c|c|c|c|c|c|c|}
\hline \multirow[t]{2}{*}{ ATCC29191 Gene ID } & \multirow[t]{2}{*}{ Product } & \multirow[t]{2}{*}{ ZM4 Gene ID } & \multicolumn{5}{|c|}{$\log _{2}$ RPKM } \\
\hline & & & $24^{\circ} \mathrm{C}$ & $30^{\circ} \mathrm{C}$ & $36^{\circ} \mathrm{C}$ & $40^{\circ} \mathrm{C}$ & $45^{\circ} \mathrm{C}$ \\
\hline ZZ6_0707 & Glucose sorbosone dehydrogenase & ZMO0558 & 7.20 & 7.16 & 7.09 & 7.15 & 7.22 \\
\hline ZZ6_1376 & 5,10-methylenetetrahydrofolate reductase & ZMO1747 & 6.39 & 6.57 & 7.20 & 7.87 & $6.08^{* *}$ \\
\hline ZZ6_1146 & Glucosamine-fructose-6-phosphate aminotransferase & ZMO0056 & 7.66 & 7.53 & 7.53 & 7.48 & $8.08^{*}$ \\
\hline ZZ6_0929 & Glycosyl transferase group & ZM00306 & 6.62 & 6.36 & 6.40 & 6.30 & $5.73^{*}$ \\
\hline ZZ6_0923 & Phospholipase D/transphosphatidylase & ZMO0314 & 6.41 & 6.42 & 6.47 & 6.50 & $6.74^{*}$ \\
\hline ZZ6_1551 & Squalene-hopene cyclase & ZMO1548 & 7.19 & 7.25 & 7.34 & 7.45 & $7.98^{* *}$ \\
\hline ZZ6_1046 & MotA/TolQ/ExbB proton channel & ZMO0161 & 7.93 & 8.12 & 7.99 & 7.69 & $6.75^{* *}$ \\
\hline ZZ6_1043 & Protein TolB & ZMO0165 & 8.56 & 8.68 & 8.45 & 8.09 & $7.91^{* *}$ \\
\hline ZZ6_1254 & Protein-export protein & ZMO1897 & 8.88 & 9.14 & 9.24 & 9.13 & $7.49^{* *}$ \\
\hline ZZ6_1477 & Import inner membrane & ZMO1636 & 9.27 & 9.34 & 9.12 & 9.29 & $10.89^{* * * *}$ \\
\hline ZZ6_0158 & Protein of unknown function & ZMO1173 & 6.85 & 7.04 & 7.19 & 7.33 & $6.78^{*}$ \\
\hline ZZ6_1210 & ComEC/Rec2-related protein & ZMO1965 & 4.84 & 5.01 & 5.17 & 5.18 & $5.52^{* *}$ \\
\hline ZZ6_0840 & MJ0042 family finger-like & ZMO0414 & 8.30 & 8.36 & 8.35 & 8.26 & $7.00^{* * *}$ \\
\hline ZZ6_0541 & Protein of unknown function & ZMO0746 & 7.47 & 7.68 & 7.70 & 7.89 & 7.56 \\
\hline ZZ6_1289 & Protein of unknown function & ZMO1860 & 7.12 & 7.14 & 7.06 & 7.02 & $6.27^{* * *}$ \\
\hline ZZ6_0616 & DNA repair protein & ZMO0663 & 5.67 & 5.66 & 5.63 & 5.82 & 5.67 \\
\hline ZZ6_0934 & Exodeoxyribonuclease 7 large & ZMO0300 & 6.50 & 6.68 & 6.71 & 6.82 & $7.39^{* *}$ \\
\hline ZZ6_0681 & DNA repair protein & ZMO0589 & 6.70 & 6.81 & 6.68 & 6.68 & $6.26^{*}$ \\
\hline ZZ6_0023 & tRNA/rRNA methyltransferase & ZMO1328 & 7.85 & 8.08 & 8.21 & 8.19 & $7.19^{*}$ \\
\hline ZZ6_1659 & Peptidase M16 domain & ZMO1422 & 7.74 & 7.46 & 7.23 & 7.20 & $6.67^{* *}$ \\
\hline ZZ6_0980 & Protease Do & ZMO0234 & 8.97 & 8.74 & 8.56 & 8.57 & $10.08^{* * * *}$ \\
\hline ZZ6_0702 & ATP-dependent helicase HrpB & ZMO0565 & 6.20 & 6.50 & 6.69 & 6.87 & $6.81^{*}$ \\
\hline ZZ6_0979 & ATPase-like, ParA/MinD & ZMO0236 & 7.06 & 7.20 & 7.13 & 7.06 & $8.98^{* * *}$ \\
\hline ZZ6_0019 & Flavoprotein WrbA & ZMO1335 & 7.56 & 7.08 & 7.07 & 7.33 & $9.44^{* * * *}$ \\
\hline ZZ6_0962 & Pseudogene & \multicolumn{6}{|c|}{ No homologue identified } \\
\hline ZZ6_0861 & Hypothetical protein & ZMO0391 & 4.23 & 4.93 & 4.24 & 2.27 & 5.70 \\
\hline
\end{tabular}

$T$-test of ZM4 cultured at $45^{\circ} \mathrm{C}$ were conducted with $30^{\circ} \mathrm{C}$ as a control, * represents a significant difference $(0.01<P$-value $<0.05),{ }^{* *}$ represents a very significant difference $(P$-value $<0.01),{ }^{* * *}$ represents $P$-value $<0.001,{ }^{* * * *}$ represents $P$-value $<0.0001$

down-regulated in ZM4 cultured at $45{ }^{\circ} \mathrm{C}$ compared to $30{ }^{\circ} \mathrm{C}$.

Genes encoding chaperonins, cell division proteins, and out membrane transporters were suggested to be associated with temperature increase, and therefore were selected together with other candidate genes obtained through bioinformatics studies and literature report for genetics studies to explore their roles on heat tolerance using strategies of plasmid overexpression and inducible promoter replacement. Genetics studies indicated that overexpression of ZMO0236, ZMO1335, ZMO0994, groESL, and an exogenous gene cspL can improve the heat tolerance of $Z$. mobilis. The heat produced by microorganisms during growth can raise the temperature of fermentation environment and then inhibit cell growth and fermentation performance, which needs costly cooling equipment to maintain normal cell growth. Our work thus not only explored the effects of temperature on the expression of endogenous and exogenous genes, but also selected and confirmed several genes associated with heat tolerance in Z. mobilis, which provided both gene candidates for heat-tolerant recombinant strain development and a guidance on identifying candidate genes associated with phenotypic improvement through systems biology strategy and genetics studies.

\section{Materials and methods}

\section{Medium, strains, and chemicals}

Rich Medium (RM) (50 g/L glucose, $10 \mathrm{~g} / \mathrm{L}$ yeast extract, $2 \mathrm{~g} / \mathrm{L} \mathrm{KH}_{2} \mathrm{PO}_{4}$ ) autoclaved at $108{ }^{\circ} \mathrm{C}$ for 30 min was used to culture ZM4 (ATCC 31821) and derived mutants. Luria-Bertani (LB) culture (10 g/L tryptone, $5 \mathrm{~g} / \mathrm{L}$ yeast extract, $10 \mathrm{~g} / \mathrm{L} \mathrm{NaCl}, \mathrm{LB}$ solid medium requires additional $15 \mathrm{~g} / \mathrm{L}$ agar) autoclaved at $121{ }^{\circ} \mathrm{C}$ for $30 \mathrm{~min}$ was used to culture E. coli DH5 $\alpha$. Glucose, $\mathrm{KH}_{2} \mathrm{PO}_{4}$, and $\mathrm{NaCl}$ were purchased from Sinopharm Chemical Reagent 

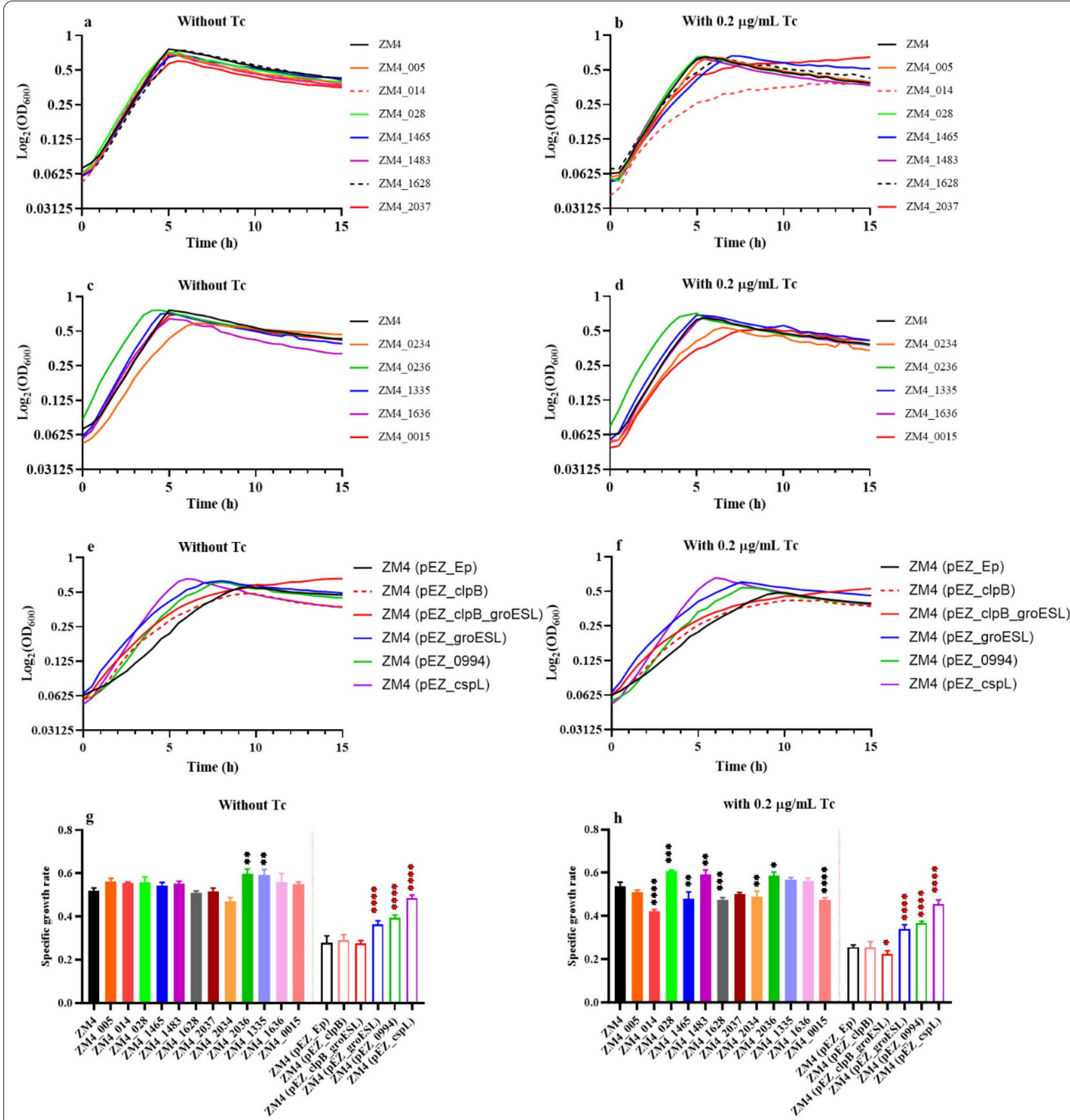

Fig. 6 Growth curves and specific growth rates of mutants at $40^{\circ} \mathrm{C}$ with the concentration of tetracycline at 0 or $0.2 \mu \mathrm{g} / \mathrm{mL}$. The tetracycline concentration in the culture medium of figures $\mathbf{a}, \mathbf{c}$, $\mathbf{e}$ and $\mathbf{g}$ was $0 \mu \mathrm{g} / \mathrm{mL}$, while the tetracycline concentration in the culture medium of figures $\mathbf{b}, \mathbf{d}, \mathbf{f}$ and $\mathbf{h}$ was $0.2 \mu \mathrm{g} / \mathrm{mL}$. The media in figures $\mathbf{a}-\mathbf{d}$ and the left of the red dashed line in figure $\mathbf{g}$ and $\mathbf{h}$ were RM, while the media in figures $\mathbf{e}$, $\mathbf{f}$ and the right of the red dashed line in figure $\mathbf{g}$ and $\mathbf{h}$ were RM supplemented with $50 \mathrm{\mu g} / \mathrm{mL}$ spectinomycin. ZM4 was wild-type strain used as the control for mutants with the native promoter replaced by an inducible promoter $\mathrm{P}_{\text {tet }}$. ZM4 (pEZ_Ep) was ZM4 strain containing a shuttle vector pEZ15Asp as the control for recombinant strains over-expressing candidate genes. ZM4_XXX referred to mutants with native promoters replaced by an inducible promoter $P_{\text {tet }}$ (for example, ZM4_005 and ZM4_1465 referred to gene pZYM36_005 and ZMO1465 with their native promoters replaced by the inducible promoter $P_{\text {tet }}$ respectively.). ZM4 (pEZ_XXX) referred to recombinant strains over-expressing candidate genes. For example, ZM4 (pEZ_clpB) referred to ZM4 with an extra copy of $c / p B$ driving by $P_{\text {tet }}$ on the shuttle vector pEZ15Asp except that groESL in ZM4 (pEZ_groESL) was driven by its native promoter. One-way ANOVA of specific growth rate of mutants at $40{ }^{\circ} \mathrm{C}$ were conducted with ZM4 or ZM4 (pEZ_Ep) as the control, ${ }^{*}$ represents a significant difference $(0.01<P$-value $<0.05)$, ${ }^{* *}$ represents a very significant difference $(P$-value $<0.01),{ }^{* * *}$ represents $P$-value $<0.001,{ }^{* * * *}$ represents $P$-value $<0.0001$ 
Co., Ltd (Shanghai, China). Yeast extract was purchased from OXOID. Agar was purchased from Guangzhou Saiguo Biotech Co., Ltd (Guangzhou, China).

\section{Flask fermentation and analytic methods}

ZM4 or ZM4_EGFP revived in an appropriate volume of $\mathrm{RM}$ at $30{ }^{\circ} \mathrm{C}$ for about $6-8 \mathrm{~h}$ at $30{ }^{\circ} \mathrm{C}$ in $\mathrm{RM}$ was used as seed culture. The seed culture of $Z$. mobilis was then used to inoculate the shake flask containing $80 \%$ of RM with a sealing gas permeable membrane sealed at an initial $\mathrm{OD}_{600}$ of 0.1 , and cultured at different temperatures $\left(24,30,36,40\right.$ and $\left.45^{\circ} \mathrm{C}\right), 100 \mathrm{rpm}$. At least three replicates were used for each condition. It should be noted that $50 \mu \mathrm{g} / \mathrm{mL}$ spectinomycin was added to the culture medium (RM) of the ZM4_EGFP to prevent the loss of pEZ_EGFP under high temperature.

The $\mathrm{OD}_{600}$ value of the bacterial culture was measured by UV-visible spectrophotometer UV-1800 (AoYi Instrument Co., Ltd, Shanghai, China) every $3 \mathrm{~h}$. At the same time, $1-\mathrm{mL}$ culture was centrifuged $(12,000 \mathrm{rpm}, 1 \mathrm{~min})$ to obtain the supernatant for measuring the glucose and ethanol concentrations in the culture using Biosensor analyzer M-100 (Sieman Technology Co., Ltd., Shenzhen, China), and a Shimadzu LC-2030 high pressure liquid chromatography (HPLC) equipped with refractive index detector (RID) and Bio-Rad Aminex HPX-87H $(300 \times 7.8 \mathrm{~mm})$ column [42]. Briefly, the supernatant was filtered through a $0.45-\mu \mathrm{m}$ filter before applying on HPLC. $0.005 \mathrm{M} \mathrm{H}_{2} \mathrm{SO}_{4}$ was used as the mobile phase at a flow rate of $0.5 \mathrm{~mL} / \mathrm{min}$, and temperatures of the detector and column were 40 and $60^{\circ} \mathrm{C}$, respectively.

At $24 \mathrm{~h}, \mathrm{ZM} 4$ cultured at different temperatures were stained by Gram-stain kit (Qingdao Hope Bio-Technology Co., Ltd, Qingdao, China) and then observed using Leica DMi8 fluorescence microscope. The live ZM4 EGFP cultured at different temperatures were observed directly using Leica DMi8 fluorescence microscope after washing twice with $1 \times$ PBS.

\section{Transcriptomic analysis and statistical analysis}

The transcriptomics study was followed previous work [37, 42-49]. Briefly, cell culture samples at different temperatures were collected during the mid-exponential phase followed by total RNA extraction and rRNA depletion using TRIzol reagent (Invitrogen, USA) and RiboZero rRNA Removal Kit (Illumina, USA), respectively. RNA-Seq was performed using paired-end sequencing technology according to standard Illumina protocols with a library construction kit $\left(\mathrm{NEBNext}^{\circledR}\right.$ Ultra $^{\mathrm{TM}}$ Directional RNA Library Prep Kit for Illumina ${ }^{\circledR}$ ) and an Illumina HiSeq instrument (Genewiz Inc, China).

RNA-Seq fastq data passing the quality control was evaluated using FastQC software (Babraham
Bioinformatics, UK) before importing into CLC Genomics Workbench (Ver. 11.0) for reads trimming and RNASeq analysis to get the RPKM value (reads mapping to the genome per kilobase of transcript per million reads sequenced) of each gene with the reference genome. Genome sequence of $Z$. mobilis was used as the reference for RPKM calculation [50]. The RPKM value of each gene was then imported into JMP Genomics (Ver. 9.0, SAS Inc., NC, USA). Data normalization and statistical analysis were conducted to identify differentially expressed genes. Triplicate samples were used for each condition. The statistical analysis involved in this study including $t$-test and one-way ANOVA, were all conducted through JMP Genomics (Ver. 9.0, SAS Inc., NC, USA).

\section{Construction of recombinant strains Construction of ZM4_EGFP strain for exogenous EGFP gene expression}

The reporter gene EGFP driven by a constitutive promoter $\mathrm{P}_{\text {lacuvs }}$ was assembled to the shuttle vector pEZ15Asp containing an origin of replication with promoters for E. coli as well as Z. mobilis [41] to construct the plasmid pEZ_EGFP (Fig. 7a). The plasmid was then transferred to ZM4 competent cells prepared as described previously through electroporation (electroporation condition: $1 \mathrm{~mm}$ electrode gap, $1600 \mathrm{~V}, 200 \Omega$, $25 \mu \mathrm{F}$ ) using a Gene Pulser $^{\circledR}$ (Bio-rad, USA) [28, 41]. Subsequently, the cells were spread on a plate containing $100 \mu \mathrm{g} / \mathrm{mL}$ spectinomycin and cultured at $30{ }^{\circ} \mathrm{C}$ for approximately 2 days. The transformants were verified by colony PCR, and then confirmed by Sanger sequencing to obtain the recombinant strain ZM4_EGFP.

\section{Construction of mutant with native promoter replaced by inducible promoter Ptet}

The native promoter of candidate gene was predicted using BPROM promoter prediction webserver at http:// www.softberry.com. Upstream (US) and downstream (DS) with length between 500 and $1000 \mathrm{bp}$ of the promoter were used as homology arms (Fig. 7b).

DNA fragment used to replace native promoters abbreviated as $\mathrm{P}_{\text {tet }}$ fragment includes the spectinomycin resistance gene $\operatorname{aad} A$, tet $R$ gene encoding the TetR repressor protein and an inducible promoter $\mathrm{P}_{\text {tet }}$ (Fig. $7 \mathrm{~b}$ ). The primer pairs for amplifying upstream (primers: US-F, US-R) and downstream (primers: DS-F, DS-R) homology arms and the promoter to be replaced (spe-ptet-F, spe-ptet- $R$ ) were designed, and all of them contained 15-20 nucleotides overlapping regions (Additional file 4: Table S4). Among them, the primers US-F and DS-R overlapped with the cloning vector pUC57 by about $20 \mathrm{bp}$. The upstream and downstream homology arms of native promoters of candidate genes were amplified from 


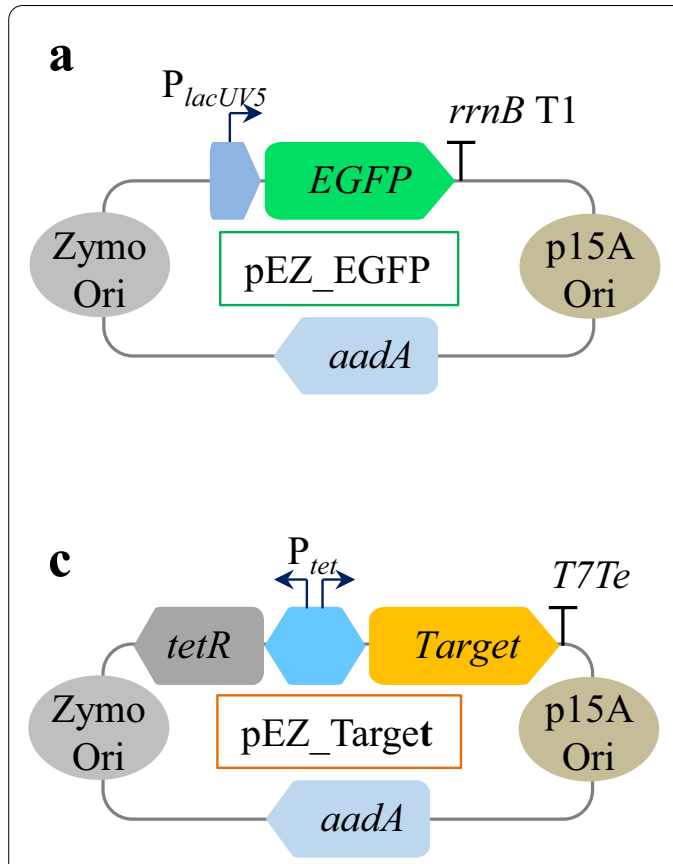

b

Native promoter of target gene on the genome

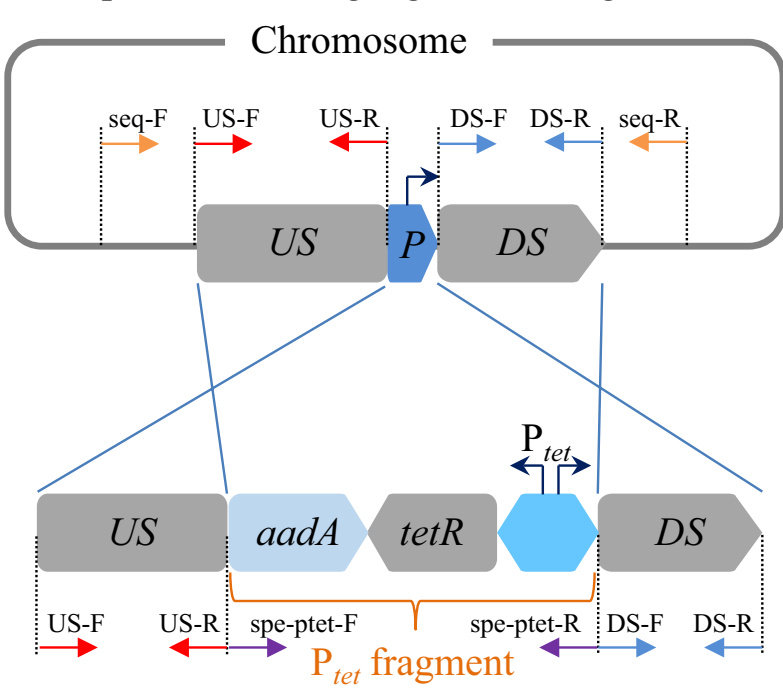

Constructed long fragment for replacing the native promoter

Fig. 7 Schematic diagram of plasmids and promoter replacement method. The constructed pEZ_EGFP (a), long fragment for replacing the native promoter of target gene on the genome (b), and pEZ_Target (Target means one of these three constructs: clpB, an operon containing CIPB_groESL with groESL driven by their native promoter, and ZMO0994) (c). $P_{\text {lacuv5 }}$ is a constitutive promoter. rrnBT1 and T7Te are terminators. Zymo Ori means an origin of replication with promoters for $Z$. mobilis. p15A Ori means an origin of replication with promoters for $E$. coli. $P$ refers to the original promoter of the gene of interest. US means the upstream of the original promoter. aadA refers to spectinomycin resistance gene. $P_{\text {tet }}$ is a bi-directional promoter, which simultaneously initiates the expression of tetR gene and the candidate gene. $P_{\text {tet }}$ fragment included aad $A$, tet $R$, and $P_{\text {tet }}$

ZM4 genomic DNA. Three DNA fragments including the upstream and downstream homology arms of native promoters of candidate genes and the $\mathrm{P}_{\text {tet }}$ fragment were assembled by overlapping PCR.

The overlapping PCR method includes two steps. The first step was to assemble a long fragment through the three fragments above. The upstream and downstream homology arms and the $\mathrm{P}_{\text {tet }}$ fragment were all $100 \mathrm{ng}$, and $10 \mu \mathrm{L} 2 \times$ PrimerStar mix was added, water was then added to a total volume of $20 \mu \mathrm{L}$. The reaction procedure for the first step was set as following: $98^{\circ} \mathrm{C} 3 \mathrm{~min},\left(98^{\circ} \mathrm{C}\right.$ $\left.15 \mathrm{~s}, 44{ }^{\circ} \mathrm{C} 20 \mathrm{~s}, 72{ }^{\circ} \mathrm{C} 30 \mathrm{~s}\right)$ for 12 cycles, $72{ }^{\circ} \mathrm{C} 2 \mathrm{~min}$. One microliter $(1 \mu \mathrm{L})$ primers of US-F and DS-R were added into $20 \mu \mathrm{L}$ reaction system from the first step at the second step. The reaction procedure for the second step was set as following: $98{ }^{\circ} \mathrm{C} 3 \mathrm{~min},\left(98^{\circ} \mathrm{C} 15 \mathrm{~s}, 55^{\circ} \mathrm{C}\right.$ $20 \mathrm{~s}, 72{ }^{\circ} \mathrm{C} 1 \mathrm{~min}$ ) for 25 cycles, $72{ }^{\circ} \mathrm{C} 2 \mathrm{~min}$.

PCR products were separated by gel electrophoresis, followed by gel purification, and subsequently quantified using NanoDrop 2000 (Thermo Fisher Scientific, USA). The long fragments from overlapping PCR and vector pUC57 were assembled by using T5 exonuclease (NEB, USA) [28], and the obtained recombinant plasmids were verified by PCR using US-F and DS-R and
Sanger sequencing. The sequencing confirmed plasmid was then transferred to ZM4 competent cells prepared as described previously through electroporation (electroporation condition: $1 \mathrm{~mm}$ electrode gap, $1600 \mathrm{~V}, 200 \Omega$, $25 \mu \mathrm{F}$.) using a Gene Pulser ${ }^{\circledR}$ (Bio-Rad, USA) to obtain the recombinant strains $[28,41]$. Subsequently, the cells were spread on a plate containing $100 \mu \mathrm{g} / \mathrm{mL}$ spectinomycin and cultured at $30{ }^{\circ} \mathrm{C}$ for approximately 2 days. The transformants were verified using primer pairs of seq-F and seq- $\mathrm{R}$ that were outside the US-F and DS- $R$ and further confirmed using Sanger Sequencing to obtain the final mutants.

\section{Construction of recombinant strains over-expressing candidate gene}

The target gene (like $\operatorname{clpB}, Z M O 0994$ ) driven by an inducible promoter $\mathrm{P}_{\text {tet }}$ was assembled to the vector $\mathrm{pEZ15Asp}$ [41] to construct the plasmid pEZ_Target (Fig. 7c), which was then transformed into ZM4 to obtain ZM4 (pEZ_ Target). The procedures for competent cell preparation, electroporation, and transformant confirmation were same as described above. The sequence information of all primers as well as vectors, genes and biological parts 
used in this article are listed in Additional file 4: Table S4 and Additional file 5: Table S5.

\section{Flow cytometry and plate reader analysis}

ZM4_EGFP cultured at different temperatures were washed with $1 \times$ phosphate-buffered saline (PBS) twice and then resuspended into PBS. Cells were analyzed by flow cytometry using Beckman CytoFLEX FCM (Beckman Coulter, USA) with the PBS as the sheath fluid, or using the SpectraMax M2e Microplate Reader (Molecular Devices, USA). The fluorescence of EGFP was excited with the $488 \mathrm{~nm}$ and detected with FITC by flow cytometry, and excited with the $485 \mathrm{~nm}$ by enzyme-labeled instrument.

\section{Western bolt}

ZM4_EGFP grown at different temperatures was harvested to conduct the western blot experiment followed previous work [28]. Cells cultured at different temperatures were harvested and lysed for total protein extraction using Protein Extraction Kit (Zomanbio, China). Total protein concentrations of samples were measured by the Bradford method. Sodium dodecyl sulphate polyacrylamide gel electrophoresis (SDS-PAGE) was performed with a $5 \%$ stacking and a $12 \%$ running gel. The loading amount of each sample was $200 \mathrm{ng}$ total protein, and a pre-stained protein ladder $(10-170 \mathrm{kDa}$, Thermo, Lithuania) was loaded for estimating molecular weight [51].

Gel was transferred to methanol-activated PVDF membranes ${ }^{\circledR}$ using the Trans-Blot Semi-Dry Electrophoretic Transfer Cell (Bio-Rad, USA) and run for $20 \mathrm{~min}$ at $25 \mathrm{~V}$. PVDF membranes was then blocked with $5 \%$ skimmed milk in phosphate-buffered saline with Tween 20 (PBST) for $1 \mathrm{~h}$ at room temperature, and subsequently EGFP was probed with the primary antibody (1:5000, Proteintech, China) for $1 \mathrm{~h}$. Peroxidase-conjugated goat anti-Mouse IgG (1:5000, Proteintech, China) was used as secondary antibody. PVDF membrane after blocking with skimmed milk, incubating primary antibody, and incubating secondary antibody was washed to remove the excess protein. Color development was performed by West Dure Extended Duration Substrate Kit (AntGene, China). All images were visualized using AI600 Imaging System (GE, USA).

\section{Characterization of recombinant strains}

Recombinant strains with the native promoter of candidate genes replaced and candidate genes overexpressed revived in an appropriate volume of $\mathrm{RM}$ at $30{ }^{\circ} \mathrm{C}$ for about $6-8 \mathrm{~h}$ prior to inoculating overnight seed cultures at $30^{\circ} \mathrm{C}$ in $\mathrm{RM}$ was used as seed culture.
The seed cultures of recombinant strains were centrifuged (12,000 rpm, $1 \mathrm{~min})$ to remove RM. Recombinant strains were resuspended, respectively, with RM and RM with $0.2 \mu \mathrm{g} / \mathrm{mL}$ tetracycline, which were then inoculated into 96-well plate containing a total volume of $200 \mu \mathrm{L}$ test medium at an initial $\mathrm{OD}_{600}$ value of 0.05 . Cells were incubated without shaking at $40{ }^{\circ} \mathrm{C}$. Triplicate were used for each condition, and turbidity measurements $\left(\mathrm{OD}_{600}\right)$ were taken every $15 \mathrm{~min}$ by the FLUOstar $^{\circledR}$ Omega (BMG LABTECH, Germany) till cells grew into stationary phase.

\section{Abbreviations}

ED: Entner-Doudoroff; EMP: Embden-Meyerhof-Parnas; GRAS: Generally regarded as safe status; RM: Rich medium; RPKM: Reads mapping to the genome per kilobase of transcript per million reads sequenced.

\section{Supplementary Information}

The online version contains supplementary material available at https://doi. org/10.1186/s13068-021-02000-1.

Additional file 1: Table S1. Glucose consumption $\left(Y_{s}\right)$, ethanol titer $\left(Y_{p}\right)$, ethanol yield $\left(Y_{p / s}\right)$, ethanol productivity $\left(Q_{p}\right)$, and specific growth rate $(\mu)$ of ZM4 or ZM4_GFP at different temperatures within $27 \mathrm{~h}$. Multiple comparisons of each parameter of ZM4 or ZM4_GFP at 24, 36, 40, and $45^{\circ} \mathrm{C}$ were conducted with ZM4 or ZM4_GFP at $30{ }^{\circ} \mathrm{C}$ as a control, * represents a significant difference $(0.01<P$-value $<0.05),{ }^{* *}$ represents a very significant difference $(P$-value $<0.01)$, ${ }^{* * *}$ represents $P$-value $<0.001$, ${ }^{* * *}$ represents $P$-value $<0.0001$.

Additional file 2: Table S2. List the differentially expressed genes of ZM4 at different temperatures. It contained a total of 6 tables which were Table S2_a, Table S2_b, Table S2_c, Table S2_d, Table S2_e, and Table S2_f, listing differentially expressed genes between ZM4 cultured at $30^{\circ} \mathrm{C}$ and $45^{\circ} \mathrm{C}(30 / 45), 30^{\circ} \mathrm{C}$ and $40^{\circ} \mathrm{C}(30 / 40), 30^{\circ} \mathrm{C}$ and $36^{\circ} \mathrm{C}(30 / 36), 24^{\circ} \mathrm{C}$ and $30{ }^{\circ} \mathrm{C}(24 / 30), 40^{\circ} \mathrm{C}$ and $45^{\circ} \mathrm{C}(40 / 45), 36^{\circ} \mathrm{C}$ and $40{ }^{\circ} \mathrm{C}(36 / 40)$.

Additional file 3: Table S3. List of eleven up-regulated genes of ZM4 cultured at $24^{\circ} \mathrm{C}$ and $45^{\circ} \mathrm{C}$ compared with $30^{\circ} \mathrm{C}$. Ratio (24/30) is the $\log _{2}$-based expression difference between ZM4 cultured at $24^{\circ} \mathrm{C}$ and $30^{\circ} \mathrm{C}$. Ratio $(45 / 30)$ is the $\log _{2}$-based expression difference between ZM4 cultured at $45^{\circ} \mathrm{C}$ and $30^{\circ} \mathrm{C}$. $P$-value is $-\log _{10}(P$-value $)$.

Additional file 4: Table S4. List of primers used in this work. The underlined sequence indicates the homology arm for overlapping PCR or plasmid assembly by T5 exonuclease.

Additional file 5: Table S5. Sequences of pEZ15A and pUC57 vectors, EGFP and cspL genes, as well as promoters and terminators used in this study.

\section{Authors' contributions}

SY conceived and designed the experiments with inputs from RL, WS, JD, ML, and $Y Y$. RL performed the experiments with the help of WS and YY. RL and SY wrote the manuscript with all authors conducted the extensive manuscript review. All authors contributed to data analyses, revised the final manuscript. All authors read and approved the final manuscript.

\section{Funding and acknowledgments}

This work was supported by National Science Foundation of China (21978071 and U1932141), National Key Research and Development Program of China (2018YFA0900300), Leading Innovative and Entrepreneur Team Introduction Program of Zhejiang Province (2018R01014), the Innovation Base for Introducing Talents of Descipline of Hubei Province (2019BJH021), and Technical Innovation Special Fund of Hubei Province (2019AHB055 and 2018ACA149). 
We also acknowledge the support from State Key Laboratory of Biocatalysis and Enzyme Engineering.

\section{Availability of data and materials}

The RNA-Seq raw data were deposited at Sequence Read Archive (SRA) database.

\section{Declarations}

\section{Ethics approval and consent to participate}

The authors declare that this study does not involve human subjects, human material and human data.

\section{Competing interests}

The authors declare that they have no competing financial interests.

\section{Author details}

${ }^{1}$ State Key Laboratory of Biocatalysis and Enzyme Engineering, Environmental Microbial Technology Center of Hubei Province, and School of Life Sciences, Hubei University, Wuhan 430062, China. ${ }^{2}$ Department of Biological and Chemical Engineering, Zhixing College of Hubei University, Wuhan 430011, China.

${ }^{3}$ China Biotech Fermentation Industry Association, Beijing 100833, China.

${ }^{4}$ Zhejiang Huakang Pharmaceutical Co., Ltd., Kaihua County, Zhejiang, China.

Received: 28 April 2021 Accepted: 18 June 2021

Published online: 27 June 2021

\section{References}

1. Hahn-Hägerdal B, Galbe M, Gorwa-Grauslund MF, Lidén G, Zacchi G. Bio-ethanol-the fuel of tomorrow from the residues of today. Trends Biotechnol. 2006;24(12):549-56.

2. Chisti Y. Biodiesel from microalgae beats bioethanol. Trends Biotechnol. 2008;26(3):126-31.

3. Conway T. The Entner-Doudoroff pathway: history, physiology and molecular biology. FEMS Microbiol Rev. 1992;9(1):1-27.

4. Xia J, Yang Y, Liu CG, Yang S, Bai FW. Engineering Zymomonas mobilis for robust cellulosic ethanol production. Trends Biotechnol. 2019;37(9):960-72.

5. He MX, Wu B, Qin H, Ruan ZY, Tan FR, Wang JL, et al. Zymomonas mobilis: a novel platform for future biorefineries. Biotechnol Biofuels. 2014;7:101.

6. Panesar PS, Marwaha SS, Kennedy JF. Zymomonas mobilis: an alternative ethanol producer. J Chem Technol Biotechnol. 2010;81(4):623-35.

7. Rogers PL, Goodman AE, Heyes RH. Zymomonas ethanol fermentations. Microbiol Sci. 1984;1(6):133-6.

8. Rogers PL, Jeon YJ, Lee KJ, Lawford HG. Zymomonas mobilis for fuel ethanol and higher value products. Adv Biochem Eng Biotechnol. 2007;108:263-88.

9. Wang X, He Q, Yang Y, Wang J, Haning K, Hu Y, et al. Advances and prospects in metabolic engineering of Zymomonas mobilis. Metab Eng. 2018;50:57-73.

10. Yang S, Fei Q, Zhang Y, Contreras LM, Utturkar SM, Brown SD, et al. Zymomonas mobilis as a model system for production of biofuels and biochemicals. Microb Biotechnol. 2016;9(6):699-717.

11. Rogers PL, Lee KJ, Skotnicki ML, Tribe DE. Ethanol production by Zymomonas mobilis. 1982;23:37-84.

12. Yang Y, Hu M, Tang Y, Geng B, Qiu M, He Q, et al. Progress and perspective on lignocellulosic hydrolysate inhibitor tolerance improvement in Zymomonas mobilis. Bioresour Bioprocess. 2018;5(1):6.

13. Zhang M, Shi J, Jiang L. Modulation of mitochondrial membrane integrity and ROS formation by high temperature in Saccharomyces cerevisiae. Electron J Biotechnol. 2015;18(3):202-9.

14. Samappito J, Yamada M, Klanrit $\mathrm{P}$, Thanonkeo P. Characterization of a thermo-adapted strain of Zymomonas mobilis for ethanol production at high temperature. 3 Biotech. 2018;8(11):474.

15. Swings J, Ley JD. The biology of Zymomonas. Bacteriol Rev. 1977:41(1):1-46.

16. Weir PM. The ecology of Zymomonas: a review. Folia Microbiol (Praha). 2016;61(5):385-92.
17. Yang Y, Geng B, Song H, He Q, He M, Bao J, et al. Progress and perspectives on developing Zymomonas mobilis as a chassis cell. Synth Biol J. 2021;2(1):59-90.

18. Cazetta ML, Celligoi MA, Buzato JB, Scarmino IS. Fermentation of molasses by Zymomonas mobilis: effects of temperature and sugar concentration on ethanol production. Bioresour Technol. 2007;98(15):2824-8.

19. Lee KJ, Skotnicki ML, Tribe DE, Rogers PL. The effect of temperature on the kinetics of ethanol production by strains of Zymomonas mobilis. Biotechnol Lett. 1981;3(6):291-6.

20. Stevnsborg N, Lawford HG, Martin N, Beveridge T. Effect of growth temperature on the morphology and performance of Zymomonas mobilis ATCC 29191 in batch and continuous culture. Appl Microbiol Biotechnol. 1986:25:116-23.

21. Kosaka T, Nishioka A, Sakurada T, Miura K, Anggarini S, Yamada M. Enhancement of thermal resistance by metal ions in thermotolerant Zymomonas mobilis TISTR 548. Front Microbiol. 2020;11:502

22. Fein JE, Bar Be RDL, Charley RC, Be Veridge TJ, Lawford HG. Effect of commercial feedstocks on growth and morphology of Zymomonas mobilis. Biotechnol Lett. 1984;6(2):123-8.

23. Benschoter AS, Ingram LO. Thermal tolerance of Zymomonas mobilis: temperature-induced changes in membrane composition. Appl Environ Microbiol. 1986;51(6):1278-84.

24. Vigants A, Upite D, Scherbaka R, Lukjanenko J, Ionina R. An influence of ethanol and temperature on products formation by different preparations of Zymomonas mobilis extracellular levansucrase. Folia Microbiol (Praha). 2013;58(1):75-80.

25. Charoensuk K, Sakurada T, Tokiyama A, Murata M, Kosaka T, Thanonkeo $P$, et al. Thermotolerant genes essential for survival at a critical high temperature in thermotolerant ethanologenic Zymomonas mobilis TISTR 548. Biotechnol Biofuels. 2017;10:204.

26. Yang J, Kim HE, Jung YH, Kim J, Kim DH, Walmsley AR, et al. Zmo0994, a novel LEA-like protein from Zymomonas mobilis, increases multi-abiotic stress tolerance in Escherichia coli. Biotechnol Biofuels. 2020;13:151.

27. Kosaka T, Nakajima Y, Ishii A, Yamashita M, Yoshida S, Murata M, et al. Capacity for survival in global warming: adaptation of mesophiles to the temperature upper limit. PLoS ONE. 2019;14(5):e0215614.

28. Yang $Y$, Shen W, Huang J, Li R, Xiao Y, Wei H, et al. Prediction and characterization of promoters and ribosomal binding sites of Zymomonas mobilis in system biology era. Biotechnol Biofuels. 2019;12:52.

29. Kremers GJ, Gilbert SG, Cranfill PJ, Davidson MW, Piston DW. Fluorescent proteins at a glance. J Cell Sci. 2011;124(2):157-60.

30. Yang $\Pi$, Cheng $L$, Kain SR. Optimized codon usage and chromophore mutations provide enhanced sensitivity with the green fluorescent protein. Nucleic Acids Res. 1996;24(22):4592-3.

31. Jayakody LN, Johnson CW, Whitham JM, Giannone RJ, Black BA, Cleveland NS, et al. Thermochemical wastewater valorization via enhanced microbial toxicity tolerance. Energ Environ Sci. 2018;11(6):1625-38.

32. Bradbeer $\mathrm{C}$. The proton motive force drives the outer membrane transport of cobalamin in Escherichia coli. J Bacteriol. 1993;175(10):3146-50.

33. Neugebauer H, Herrmann C, Kammer W, Schwarz G, Braun V. ExbBDDependent transport of maltodextrins through the novel mala protein across the outer membrane of Caulobacter crescentus. J Bacteriol. 2006:187(24):8300-11.

34. Chu BC, Peacock RS, Vogel HJ. Bioinformatic analysis of the TonB protein family. Biometals. 2007;20(3-4):467-83.

35. Stork M, Grijpstra J, Bos MP, Torres CM, Devos N, Poolman JT, et al. Zinc Piracy as a mechanism of Neisseria meningitidis for evasion of nutritional immunity. Plos Pathog. 2013;9(10):e1003733.

36. Sverzhinsky A, Fabre L, Cottreau AL, Biot-Pelletier DM, Khalil S, Bostina M, et al. Coordinated rearrangements between cytoplasmic and periplasmic domains of the membrane protein complex ExbB-ExbD of Escherichia coli. Structure. 2014;22(5):791.

37. Zhao XQ, Xue C, Ge XM, Yuan WJ, Wang JY, Bai FW. Impact of zinc supplementation on the improvement of ethanol tolerance and yield of self-flocculating yeast in continuous ethanol fermentation. J Biotechnol. 2009;139(1):55-60.

38. Zhao XQ, Bai FW. Zinc and yeast stress tolerance: micronutrient plays a big role. J Biotechnol. 2012;158(4):176-83.

39. Carman GM, Han GS. Regulation of phospholipid synthesis in Saccharomyces cerevisiae by zinc depletion. Biochim Biophys Acta. 2007:1771(3):322-30. 
40. Zhou Z, Tang H, Wang W, Zhang L, Su F, Wu Y, et al. A cold shock protein promotes high-temperature microbial growth through binding to diverse RNA species. Cell Discov. 2021;7(1):15.

41. Yang S, Mohagheghi A, Franden MA, Chou YC, Chen X, Dowe N, et al. Metabolic engineering of Zymomonas mobilis for 2,3-butanediol production from lignocellulosic biomass sugars. Biotechnol Biofuels. 2016;9(1):189

42. Li R, Jin M, Du J, Li M, Chen S, Yang S. The Magnesium concentration in yeast extracts is a major determinant affecting ethanol fermentation performance of Zymomonas mobilis. Front Bioeng Biotechnol. 2020;8:957.

43. Franden MA, Pienkos PT, Zhang M. Development of a high-throughput method to evaluate the impact of inhibitory compounds from lignocellulosic hydrolysates on the growth of Zymomonas mobilis. J Biotechnol. 2009;144(4):259-67.

44. Martinez-Moreno R, Morales P, Gonzalez R, Mas A, Beltran G. Biomass production and alcoholic fermentation performance of Saccharomyces cerevisiae as a function of nitrogen source. FEMS Yeast Res. 2012;12(4):477-85.

45. Lozano Terol G, Gallego-Jara J, Sola Martinez RA, Canovas Diaz M, de Diego Puente T. Engineering protein production by rationally choosing a carbon and nitrogen source using E. coli BL21 acetate metabolism knockout strains. Microb Cell Fact. 2019;18(1):151.

46. Kemsawasd V, Viana T, Ardo Y, Arneborg N. Influence of nitrogen sources on growth and fermentation performance of different wine yeast species during alcoholic fermentation. Appl Microbiol Biotechnol. 2015;99(23):10191-207.
47. Klotz S, Kuenz A, Prusse U. Nutritional requirements and the impact of yeast extract on the D-lactic acid production by Sporolactobacillus inulinus. Green Chem. 2017;19(19):4633-41.

48. Yang S, Franden MA, Yang Q, Chou YC, Zhang M, Pienkos PT. Identification of inhibitors in lignocellulosic slurries and determination of their effect on hydrocarbon-producing microorganisms. Front Bioeng Biotechnol. 2018;6(23):23.

49. Yang Q, Yang YF, Tang Y, Wang X, Chen YH, Shen W, et al. Development and characterization of acidic-pH-tolerant mutants of Zymomonas mobilis through adaptation and next-generation sequencing-based genome resequencing and RNA-Seq. Biotechnol Biofuels. 2020;13(1):144.

50. Yang S, Vera JM, Grass J, Savvakis G, Moskvin OV, Yang Y, et al. Complete genome sequence and the expression pattern of plasmids of the model ethanologen Zymomonas mobilis ZM4 and its xylose-utilizing derivatives $8 \mathrm{~b}$ and 2032. Biotechnol Biofuels. 2018;11:125.

51. Shu M, Shen W, Yang S, Wang X, Wang F, Wang Y, et al. High-level expression and characterization of a novel serine protease in Pichia pastoris by multi-copy integration. Enzyme Microb Technol. 2016:92:56-66.

\section{Publisher's Note}

Springer Nature remains neutral with regard to jurisdictional claims in published maps and institutional affiliations.
Ready to submit your research? Choose BMC and benefit from:

- fast, convenient online submission

- thorough peer review by experienced researchers in your field

- rapid publication on acceptance

- support for research data, including large and complex data types

- gold Open Access which fosters wider collaboration and increased citations

- maximum visibility for your research: over $100 \mathrm{M}$ website views per year

At BMC, research is always in progress.

Learn more biomedcentral.com/submissions 